\title{
Streptomyces Spinosus Sp. Nov. And Streptomyces Shenzenensis Subsp. Endophyticus Subsp. Nov. Endophytic Actinobacteria Isolated From Jasmine Rice and Their Genome Mining Correlate With Potential as Antibiotic Producers and Plant Growth Promoters
}

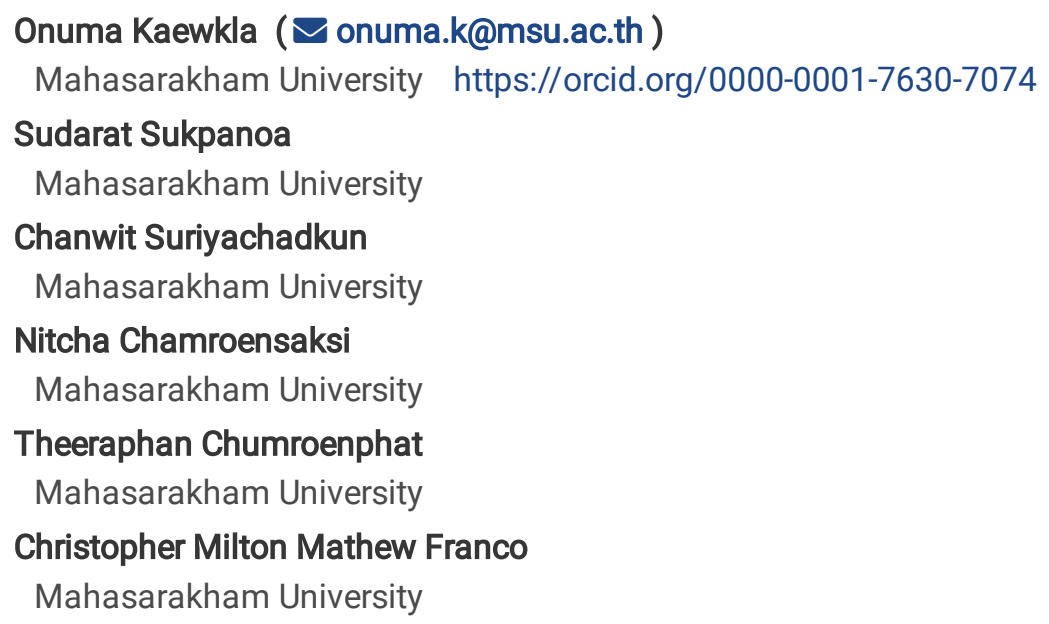

\section{Research Article}

Keywords: Streptomyces spinosus, Streptomyces shenzenensis subsp. endophyticus, endophyte actinobacterium, Plant growth promoting, genome mining

Posted Date: January 20th, 2022

DOI: https://doi.org/10.21203/rs.3.rs-1200349/v1

License: (1) (1) This work is licensed under a Creative Commons Attribution 4.0 International License. Read Full License 


\section{Abstract}

Two endophytic actinobacteria, strains SBTS $01^{\top}$ and $\mathrm{W} 18 \mathrm{~L} 9^{\top}$, were isolated from leaf sheath tissue and leaf sample of Jasmine rice (Oryza sativa KDML 105), respectively, grown in a rice paddy field in Roiet Province, Thailand. The polyphasic study showed that both strains belonged to the genus Streptomyces; they are aerobe, with well-developed substrate mycelia and aerial mycelia to form long chains of spores. Strain SBTS $01^{\top}$ shared the highest $16 \mathrm{~S}$ rRNA gene sequence similarity with Streptomyces rochei NRRL B-2410 ${ }^{\top}$ (99.0\%) and Streptomyces naganishii NRRL ISP-5282 ${ }^{\top}$ (99.0\%). Strain W18L9 ${ }^{\top}$ shared the highest $16 \mathrm{~S}$ rRNA gene sequence similarity with Streptomyces shenzhenensis DSM $42034^{\top}$. The genotypic and phenotypic data of strains SBTS01 ${ }^{\top}$ and W18 $\mathrm{L}^{\top}$ distinguished these two strains with the closely related species with valid names. The genome analysis showed the $\mathrm{dDDH}, \mathrm{ANIb}$ and ANIm values of the draft genome between strain SBTS01${ }^{\top}$ and its related species; S. rochei NRRL B-2410 ${ }^{\top}$ (29.4, 81.1, 86.5\%) and W18L9 ${ }^{\top}$ and its closest species; S. shenzhenensis DSM $42034^{\top}(72.5,95.1,97.0 \%)$. The name proposed for the new species of type strain SBTS01 ${ }^{\top}$ is Streptomyces spinosus (=NRRL B-65636 ${ }^{\top}=$ TBRC $15052^{\top}$ ). The name proposed for the

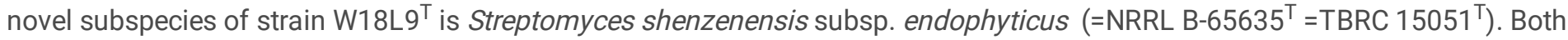
strains could produce antibiotics to inhibit pathogens and contained plant growth promoting (PGP) traits. Genome mining of these two strains revealed that they comprised many Biosynthesis Gene Clusters (BGCs); terpene, type 1, 2 and 3 polyketide synthase, Non-ribosomal peptide synthetase (NRPS), and lanthipeptide including genes encoding PGP traits; nitrogen fixation, ACC (1aminocyclopropane-1-carboxylate) deaminase and siderophore production.

\section{Introduction}

The genus Streptomyces belongs to the family Streptomycetaceae which was proposed by Waksman and Henrici (1943). The genus contains more than 900 validly published species and 50 validly published subspecies

(https://lpsn.dsmz.de/genus/streptomyces) (Parte et al. 2020). Most of them were isolated from soil as well as from various environments such as marine sediments, seawater, fresh water, caves, animals and plant tissues (Kämpfer 2012). Streptomyces spp. are well recognized as producers of bioactive compounds, especially antibiotics, as more than 70 percent of currently known antibiotics are produced by this genus. Also, there are many reports of its application as plant growth promoters by producing phytohormones, solubilize phosphate, inhibiting plant pathogens and inducing the plant immune system (Conn et al. 2008; Kämpfer 2012). There have been many studies of isolation and application of endophytes belonging to the genus Streptomyces as biocontrol agents and plant growth promoters (Barnett et al. 2019; Xu et al. 2019). Recently, genome mining is a high throughput method for discovering new drugs and searching for beneficial strains to use as plant growth promoters (Luo et al. 2014; Abdelmohsen et al. 2015). Also, many BGCs are known as "silent" or "cryptic" which may not express to produce bioactive compounds in a laboratory or require some inducers (van Bergeijk et al. 2020).

Jasmine rice (Oryza sativa KDML 105) or Khao Dawk Mali of Thailand containing aroma compound, 2-acetyl-1-pyrroline (2AP) has expanded wide popularity in Asia and the Middle East (Wakte et al. 2017). However, this rice variety is susceptible to blast causing by Pyricularia oryzae and bacterial leaf blight caused by Xanthomonas oryzae pv. oryzae (Kampapongsa and Kaewkla, 2016). Recently, there were some studies of endophytic actinobacteria from rice and their application to inhibit rice pathogens and promote rice growth (Naik et al. 2009; Rungin et al. 2012; Kampapongsa and Kaewkla 2016; Xu et al. 2019; Gao et al. 2021; Saikia and Bora, 2021). Currently, there are two valid species of the genus Streptomyces isolated from rice tissue; Streptomyces oryza (Mingma et al. 2015) and Streptomyces roietensis (Kaewkla and Franco, 2017).

In this study, the taxonomic position of endophytic actinobacteria isolated from Jasmine rice, strains SBTS $01^{\top}$ and $\mathrm{W} 18 \mathrm{~L} 9^{\top}$ were determined by using a polyphasic taxonomic approach, including morphological, physiological, chemotaxonomic, phylogenetic and genomic characteristics. Antibiotic production against rice and human pathogens and plant growth promoting studies were conducted. Genome data mining of these two strains was also reported and showed the correlation with these properties.

\section{Materials And Methods}

\section{Isolation of strains $\mathrm{SBTS}^{\mathrm{T}} 1^{\top}$ and $\mathrm{W} 18 \mathrm{~L} 9^{\mathrm{T}}$}


Strains SBTS $01^{\top}$ and $\mathrm{W} 18 \mathrm{~L} 9^{\top}$ were obtained from a project which focused on the biodiversity of endophytic actinobacteria from Jasmine rice plants and their application as plant growth promoters and biocontrol agents to inhibit plant pathogens. Jasmine rice (Oryza sativa KDML 105) was collected from the grounds of the Rice Research Centre paddy field, Roi Et province, Thailand (15.54937N 103.80975E) and surface sterilized by applying the previously described method (Kampapongsa and Kaewkla 2016). Surface-sterilized leaf, leaf sheath, stem and root tissue were placed onto three different media (Kampapongsa and Kaewkla 2016). Plates were kept in sealed plastic boxes, which were moistened with wet paper towels, and incubated at $27^{\circ} \mathrm{C}$ for 12 weeks. Actinobacterial strains were purified by using half strength potato dextrose agar (HPDA) and stored on HPDA slants at $4^{\circ} \mathrm{C}$ and in $20 \%$ glycerol at $-80^{\circ} \mathrm{C}$.

\section{Phylogenetic analysis of $16 \mathrm{~S}$ rRNA gene}

Genomic DNA of strains SBTS01 ${ }^{\top}$ and W18L9 ${ }^{\top}$ was extracted by using GenElute ${ }^{\mathrm{mm}}$ (Sigma), and the 16S rRNA gene was amplified and sequenced as described previously (Kaewkla and Franco 2013). The 16S rRNA gene sequence of these two strains was examined by using EzbioCloud server (Yoon et al. 2017), and subsequently aligned with the 16S rRNA gene sequences (available from GenBank/EMBL) of the closely related members of the genus Streptomyces with validly published names, using CLUSTAL X (Thompson et al. 1997) with Nocardia africana DSM $44491^{\top}$ as the out-group.

The phylogenetic trees were constructed by the neighbor-joining (NJ) and maximum parsimony (MP) algorithms using the software package MEGA version X (Kumar et al. 2018). The Jukes-Cantor method (Jukes and Cantor 1969) was applied to the analysis with the NJ algorithm (Saitou and Nei 1987). The MP tree was obtained using the min-mini heuristic algorithm with a search factor of 1 (Nei and Kumar 2000). The topology of the tree was evaluated by performing

a bootstrap analysis based on 1000 replications (Felsenstein 1985).

\section{Sequencing, assembly, annotation}

Genomic DNA of strain W18L9 ${ }^{\top}$ for whole genome sequencing was extracted by using GenElute ${ }^{\mathrm{TM}}$ (Sigma). For genome sequencing of this strain, library was prepared by using short insert size library and samples were sequenced by using Illumina Hiseq X-ten platform (Illumina) (2x150 bp paired-end reads) at the Beijing Genome Institute (BGI), Hongkong.

For whole genome sequencing of strain SBTS01 ${ }^{\top}$ and the type strain, S. shenzenensis DSM $42031^{\top}$, genomic DNA was extracted according to the previously described protocol (Saito and Miura 1963). A library was prepared by using microbial short insert size library (PCR free library)

and samples were sequenced by using the Novaseq 6000 systems, Hiseq PE (Illumina) (2x150 bp paired-end reads) at the Singapore Joint Venture and Sequencing Center, Novogene AIT.

The reads were De novo assembled by using Unicycler (0.4.8) (Wick et al. 2017). The draft assemblies of genomes of strains SBTS01 ${ }^{\top}$, W18L9 ${ }^{\top}$ and S. shenzenensis DSM $42031^{\top}$ have been submitted to GenBank as accession number JAINRC000000000, JACBWY000000000, and JAJONF000000000, respectively. Genomes of strains SBTS01 ${ }^{\top}$ and W18L9 ${ }^{\top}$ were annotated by using Prokka version 1.14.5 (Seemann 2014) and the NCBI Prokaryotic Genome Annotation Pipeline (PGAP) (Tatusova et al. 2016).

\section{Genome comparison}

The phylogenomic tree of strains SBTS01 ${ }^{\top}, \mathrm{W} 18 \mathrm{~L} 9^{\top}$ and related taxa was constructed by using the Type (Strain) Genome Server (TYGS) (Meier-Kolthoff et al. 2013; Meier-Kolthoff and Göker 2019). The tree inferred with FastME 2.1.6.1 (Lefort et al. 2015) from Genome BLAST Distance Phylogeny (GBDP) distances calculated from genome sequences. The branch lengths were scaled in terms of GBDP distance formula d4. Digital DNA-DNA hybridization (dDDH) values

between strains $\mathrm{SBTS}^{\top}{ }^{\top}$ and $\mathrm{W} 18 \mathrm{~L}{ }^{\top}$ and their related type strains were calculated by using the Genome-to-Genome Distance calculator (GGDC 2.1; BLAST + method) applying formula 2 (identities/HSP length) (Meier-Kolthoff et al. 2013). 
ANI-BLAST (ANIb) and ANI-MUMmer (ANIm) algorithms within the JspeciesWS web service were applied to calculate Average Nucleotide Identity values (ANI) between strain SBTS $01^{\top}$ and $\mathrm{W} 18 \mathrm{~L} 9^{\top}$ and its related species with pairwise genome alignment (Richter and Rosselló-Móra 2009; Richter et al. 2016).

\section{Chemotaxonomic characterization}

Chemotaxonomic characterization of strain $\mathrm{SBTS} 01^{\top}$ and $\mathrm{W} 18 \mathrm{~L} 9^{\top}$ was done according to the standard procedures. Whole-cell sugars were analyzed by the TLC method (Hasegawa et al. 1983) and diaminopimelic acid (DAP) was detected by Thin Layer Chromatography (TLC) (Bousfield et al. 1985). Extraction and purification of isoprenoid quinones were performed using the previously

described method (Minnikin et al. 1984). The purified menaquinones were analyzed by reverse phase LC-MS and electrospray mass spectrometry (ESI) (Shimadzu LCMS-8030). The column was InertSustain ${ }^{\circledR}$ C18 $(2.1 \times 150 \mathrm{~mm}, 3 \mu \mathrm{m})$, and the solvent system was isopropanol:methanol (1:1) at a flow rate of $0.4 \mathrm{~mL} / \mathrm{min}$ (Kaewkla and Franco 2019). The polar lipid was analyzed as described previously by using $5 \%$ ethanolic molybdophosphoric acid, Dragendorff and molybdenum blue reagents, anisaldehyde, a-naphthol and ninhydrin sprays (Minnikin et al. 1984; Komagata and Suzuki 1987).

The fatty acid methyl esters (FAMEs) of strains SBTS01 ${ }^{\top}$ and W18L9 ${ }^{\top}$ and their closest type strains were analyzed for FAMEs under the same conditions by following the protocol described by Microbial Identification Inc. (MIDI) (Sasser 2001). The two closest type strains of strain SBTS $01^{\top}$ were $S$. rochei NRRL B- $2410^{\top}$, and S. naganishii NRRL ISP-5282 ${ }^{\top}$ and the four closest types strains of strain W18L9 ${ }^{\top}$ were $S$. shenzhenensis DSM $42034^{\top}$, S. graminisoli NBRC $108883^{\top}$, Streptomyces jiujiangensis DSM $42115^{\top}$, and Streptomyces hyaluromycini DSM $100105^{\top}$. These type strains were obtained from ARS type culture collection, USA (NRRL strain), German Culture Collection (DSMZ), Germany (DSM strains) and Biological Resource Center, National Institute of Technology and Evaluation (NITE), Japan (NBRC strains). All these cultures were grown for 7 days at $27^{\circ} \mathrm{C}$ in Tryptic Soya Broth (Oxoid) in an Erlenmeyer flask at $150 \mathrm{rpm}$ and harvested by centrifugation. Washed cells were saponified, methylated and extracted for FAME analysis. The Sherlock software version 6.4 was used for analysis.

\section{Phenotypic Characterization}

Based on 16S rRNA gene similarity, the two closest type strains of strain SBTS01 ${ }^{\top}$ and four closest type strains of strain W18L $9^{\top}$ as stated above, were studied in a side-by-side comparison for phenotypic characterization. Morphological characteristics of strains SBTS01 ${ }^{\top}$, W18L9 ${ }^{\top}$ and their closest type strains were studied on 8 different media: ISP 2, ISP 3, ISP 4, ISP 5 , ISP 7 (ISP; International Streptomyces Project) (Shirling and Gottlieb 1966; Atlas and Parks 1993), Bennett's agar, HPDA and Nutrient agar (NA) (Atlas and Parks 1993). ISP 7 was used to test for melanin pigment production. Color determination was based on Methuen Handbook of Color (Kornerup and Wanscher 1978). Catalase production, assimilation of six organic acids and utilization of four phenolic compounds as sole carbon source, hydrolysis of skim milk and

starch were tested according to the previously described procedures (Kurup and Schmitt 1973). Decomposition of L-tyrosine, adenine, xanthine, urea, esculin, hippurate and acid production from eighteen carbohydrates were carried out according to the previously described methods (Gordon et al. 1974). Growth at different $\mathrm{NaCl}$ concentrations $(1,3,5,10,15$ and $20 \%$, w/v), temperatures $\left(4,15,27,37,45\right.$ and $55^{\circ} \mathrm{C}$ ), and pH between 4 and 10 (in $1 \mathrm{pH}$ unit intervals and $\mathrm{pH}$ was adjusted aseptically after autoclaving) were evaluated after incubation for 14 days on ISP 2 medium (Kurup and Schmitt 1973).

\section{Scanning Electron Microscopy (SEM)}

Strains SBTS $01^{\top}$ and $\mathrm{W} 18 \mathrm{~L} 9^{\top}$ were cultured on HPDA at $27^{\circ} \mathrm{C}$ for 7 days and cells and spores were visualized by Scanning Electron Microscopy (The Carl Zeiss version AURIGA) at the Center for Scientific Equipment and Technological Equipment, Suranaree University of Technology, Thailand. The sample preparation was carried out according to a previously described protocol (Kaewkla and Franco 2019).

\section{In vitro antibacterial and antifungal activity}


The bacteria used for the antibacterial bioassay were a rice pathogen; Xanthomonas oryzae pv. oryzae (Xoo) PXO 86, human pathogens; Staphylococcus aureus ATCC 29213 and Methicillin Resistant Staphylococcus aureus (MRSA) 03120385. The bacterial assay was modified from the dual culture method (Williston et al. 1947; Kaewkla and Franco et al. 2021). There were four fungal pathogens; Curvularia lunata BCC 15558, Helminthosporium oryzae DOAC 1570, Pyricularia grisea BRIP 61689 and Rhizoctonia solani AG8. Xoo PXO 86 and R. solani AG8 were obtained from Department of Medical Biotechnology, Flinders university. S. aureus ATCC 29213 and MRSA 03120385 were obtained from the Clinical Microbiology Department, the Flinders University, South Australia. P. grisea BRIP 61689 were obtained from Plant Pathology

Herbarium, Department of Agriculture and Forestry, Queensland, Australia. Strain DOAC 1570 and BCC 15558 were obtained from the Plant Protection Research and Development office, Thailand and the Thailand Biological Resource Center (TBRC), respectively. The fungal assay was carried out according to the dual culture method previously described protocol (Kampapongsa and Kaewkla 2016).

\section{Antibiotics production assay}

Strain SBTS $01^{\top}$ and $\mathrm{W} 18 \mathrm{~L} 9^{\top}$ were tested for antibiotics production by agar diffusion assay. Both strains were cultured on ISP 2 agar and HPDA for 7 days and whole agar plate was cut to small pieces and extracted with $100 \%$ methanol and shaken for three hours. The methanol extract was evaporated by using an evaporator. Then, extracted compound was freeze dried by using a lyophilizer. The dried samples were dissolved with $70 \%$ methanol and tested for antibiotics production against $S$. aureus ATCC 29213, MRSA 03120385 and Xoo PXO 86 according to the agar diffusion assay described by Kaewkla and Franco (2021).

For antifungal assay against $P$. grisea BRIP 61689, a fungi was grown on Potato Dextrose agar (PDA, Oxoid) at pH 6.0 for 7 days. A plug was cut at the edge of the radial growth of fungi by using a $6 \mathrm{~mm}$ cork borer and placed at the centre of a new PDA plate at $\mathrm{pH} 6.0$ and incubated at $27^{\circ} \mathrm{C}$ for 4 days or until the diameter of the fungi was about $2.5 \mathrm{~cm}$. Then, six wells were made by using a $6 \mathrm{~mm}$ cork borer with the centre of the wells approximately $1.5 \mathrm{~cm}$ away from the edge of the PDA plate. Fifty microliters of each extracted compound were put into the wells. Each sample was repeated in triplicate. Methanol was used as a negative control. Also, plate of fungi without making wells was used as a negative control. The growth of fungi was measured toward the direction of each well in 4 days after the test.

\section{Indole acetic acid (IAA) production}

The production of IAA was studied according to the method of Khamna et al. (2009) with some modifications. One actinobacterium disc $(8 \mathrm{~mm}$ ) of 7-day growth on HPDA was inoculated into ISP 2 broth supplemented with $0.2 \%$ (w/v) Ltryptophan, on a rotary shaker at $150 \mathrm{rpm}$ for 7 days in the dark at $28^{\circ} \mathrm{C}$. The cultures were centrifuged at $6000 \mathrm{~g}$ for $10 \mathrm{~min}$. The supernatant was analyzed for IAA production according to the method of Glickmann and Dessaux (1995) by using Salkowski's reagent.

\section{Cytokinin production}

The cytokinin production of strain SBTS $01^{\top}$ and $\mathrm{W} 18 \mathrm{~L} 9^{\top}$ was carried out according to the previously described method (Hussain and Husnain 2009). One actinobacterium disc $(8 \mathrm{~mm}$ ) was inoculated into Yeast malt extract casamino acid broth (Malt extract 10 $\mathrm{g}$, Yeast extract $1 \mathrm{~g}$, Glucose $4 \mathrm{~g}$, casamino acid $3 \mathrm{~g}, \mathrm{Na}_{2} \mathrm{HPO}_{4} 0.5 \mathrm{~g}$, DO water $1 \mathrm{~L}$ ) on a rotary shaker at $150 \mathrm{rpm}$ for 7 days in the dark at $28{ }^{\circ} \mathrm{C}$. The cultures were centrifuged at $10000 \mathrm{~g}$ for $10 \mathrm{~min}$. The supernatant was analyzed for cytokinins by using reverse phase HPLC (Prontosil, Hypersorb ODS $5.0 \mu \mathrm{m}$, photodiode array; $265 \mathrm{~nm}$ ), eluted with a flow rate of $1 \mathrm{ml} / \mathrm{min}$ with gradient elution of acetonitrile and $0.1 \mathrm{M}$ acetic acid in $5 \%$ acetonitrite, at the Central Laboratory, Faculty of Agriculture, Chiang Mai University, Chiang Mai, Thailand. Total cytokinins were analyzed as free cytokinins; zeatin, zeatin riboside, $N^{6}\left(D^{2}\right.$-isopentenyl) adenine and $N^{6}\left(D^{2}\right.$ - isopentenyl) adenosine.

\section{Siderophore production}

Siderophore production of strain SBTS01${ }^{\top}$ and $\mathrm{W} 18 \mathrm{~L} 9^{\top}$ was tested according to the previously described method (Pérez-Miranda et al. 2007). Briefly, actinobacterium was streaked on HPDA and grown for 7 days. Chrome azurol S (CAS) medium added agarose 
as a solidified agent was poured at the top of the HPDA plate and left for $15 \mathrm{~min}$. The positive result with changing from blue to purple indicated catechol type or from blue to orange indicated hydroxamates type.

\section{Phosphate solubilization}

The ability of strain SBTS $01^{\top}$ and $\mathrm{W} 18 \mathrm{~L} 9^{\top}$ for phosphate solubilization was tested by applying the standard method (Castagno et al. 2011). NBRIP agar was used and a positive result was observed by measuring the halo zone around colonies of these two strains after incubation for 14 days.

\section{1-aminocyclopropane-1-carboxylic acid (ACC) deaminase production}

The ability of strains SBTS $01^{\top}$ and $\mathrm{W} 18 \mathrm{~L} 9^{\top}$ to produce ACC deaminase was tested by using the DF agar (Penrose and Glick 2003). Growth on DF medium added ACC as nitrogen source was compared to growth on DF medium with and without nitrogen source as negative and positive controls, respectively.

\section{Nitrogen fixation assay}

The method of nitrogen fixation of strains $\mathrm{SBTS}^{\top}{ }^{\top}$ and $\mathrm{W} 18 \mathrm{~L}^{\top}$ in vitro was applied by the following methods (Baldani et al. 1997). Nitrogen-free semi solid (NFb) agar was used and a positive result was detected by the color of the indicator changing from light blue to dark blue.

\section{Hydrogen cyanide production}

The method of hydrogen cyanide production of two strains was applied by the following procedure (Bakker and Schippers, 1987).

\section{Cellulase production}

Strains SBTS01 ${ }^{\top}$ and $\mathrm{W} 18 \mathrm{~L}^{\top}$ were tested for cellulase production on carboxymethyl cellulose (CMC) agar plates and the positive result was detected by a congo red method according to the previously described protocol (Islam and Roy 2018).

\section{Secondary metabolite and biosynthesis gene cluster prediction}

Secondary metabolite Analysis Shell (anti-SMASH) version 6.0 (Blin et al. 2021) was used to predict biosynthetic gene clusters (BGCs) for secondary metabolite synthesis of strains SBTS01 ${ }^{\top}$ and $\mathrm{W} 18 \mathrm{~L} 9^{\top}$. The genomes of strains SBTS01 ${ }^{\top}$ and $\mathrm{W} 18 \mathrm{~L} 9^{\top}$ were examined by in silico approach to search genes encoding metabolite products relating to various properties: bioactive compound production, plant growth promoting traits, degradable enzymes and bioremediation. The closest similarity of microorganisms was acquired by applying blastp on the UniProt database with matrix; blosum62 (The UniProt 2021).

\section{Results \& Discussion}

\section{Isolation of strains $\mathrm{SBTS}^{\mathrm{S}} 1^{\top}$ and $\mathrm{W} 18 \mathrm{~L} 9^{\top}$}

Strain SBTS01 ${ }^{\top}$ was isolated from Jasmine rice (Oryza sativa KDML 105) and arose as a dark green colony on leaf sheath tissue after incubation for nine weeks on Humic acid vitamin B agar (HVA) (Hayakawa and Nonomura 1987). Strain W18L9 ${ }^{\top}$ was also isolated from Jasmine rice and emerged as a white colony on leaf tissue after incubation for two weeks on Tap Water Yeast extract agar (TWYA) (Coombs and Franco 2003).

\section{Phylogenetic analysis of the 16S rRNA gene}

The phylogenetic evaluation of strains SBTS $01^{\top}$ and $\mathrm{W} 18 \mathrm{~L} 9^{\top}$ with the closely related members of the genus Streptomyces showed that both strains belonged to genus Streptomyces and were encompassed by other members of this genus (Fig 1 and Fig S1). Strain SBTS01 ${ }^{\top}$ shared 16 S rRNA gene similarity at $98.6 \%$ with strain $\mathrm{W} 18 \mathrm{~L} 9^{\top}$. Both strains were placed in different clusters in both trees. Based on these results, both strains were considered as different species. 
The closest type strains which shared the highest $16 \mathrm{~S}$ rRNA gene sequence similarity with strain SBTS01 ${ }^{\top}$ were $S$. rochei NRRL B$2410^{\top}$ and $S$. naganishii NBRC $12892^{\top}$, both at $99.0 \%$. However, strain SBTS01 ${ }^{\top}$ formed a different cluster with these type strains and formed a single phylogenic lineage in both trees (Fig 1 and Fig S1). The type strains which shared the highest 16S rRNA gene sequence similarity with strain W18L9 $9^{\top}$ were $S$. shenzhenensis DSM $42034^{\top}$, S. graminisoli NBRC $108883^{\top}$, S. jiujiangensis DSM $42115^{\top}$, and $S$. hyaluromycini DSM $100105^{\top}$ at $99.7,99.2,98.9$, and $98.9 \%$, respectively. The closest neighbor of strain W18L ${ }^{\top}$ positioning in the same clade was S. shenzhenensis DSM $42034^{\top}$ in both trees with high bootstrap support at 81 and 67 , respectively (Fig. 1 and Fig. S1).

Based on the percentage of $16 \mathrm{~S}$ rRNA gene similarity and phylogenetic position of strains SBTS01${ }^{\top}$ and W18L9 ${ }^{\top}$, two closely related type strains of strain SBTS $01^{\top}$ and four closely related type strains of strain $\mathrm{W} 18 \mathrm{~L} 9^{\top}$ as mentioned above were selected for a side-by-side comparison study.

\section{Genome analysis}

\section{Genome comparison between strains $\mathrm{SBTS}^{\mathrm{S}} \mathrm{1}^{\top}$ and $\mathrm{W} 18 \mathrm{~L} 9^{\top}$}

The phylogenetic tree based on TYGS revealed that strain $\mathrm{SBTS}_{01}{ }^{\top}$ was placed in the different species cluster with strain $\mathrm{W} 18 \mathrm{~L} 9^{\top}$ (Fig S2). The genome analysis showed the $\mathrm{dDDH}, \mathrm{ANIb}$ and ANIm values of the draft genome between strain SBTS01 ${ }^{\top}$ and strain W18 $\mathrm{L}^{\top}$ being $28.3 \%, 81.6 \%$ and $87.1 \%$, respectively which were well below the threshold for species delineation (Meier-Kolthoff et al. 2013; Chun et al. 2018). Based on a genome comparison study, both strains were in different species. Genome features of strains SBTS01 ${ }^{\top}, \mathrm{W} 18 \mathrm{Lg}^{\top}$ and their closest type strains were shown on Table S1.

\section{Genome comparison of strain SBTS01 ${ }^{\top}$}

The draft genome sequence of strain $\mathrm{SBTS} 01^{\top}$ was $9.17 \mathrm{Mb}$ with DNA G+C content determined by in silico genome sequence as $72.5 \mathrm{~mol} \%$. The phylogenetic tree based on TYGS revealed the relationship between strain SBTS01 ${ }^{\top}$ and the related type strains. The phylogenomic tree showed that strain $\mathrm{SBTS}^{\top} 1^{\top}$ was placed in the different species cluster from all related type strains (Fig. S2). Strain SBTS $01^{\top}$ formed a single phylogenetic cluster with the closest neighbour, Streptomyces corchorusii DSM $40340^{\top}$, while it positioned away from the closest type strains, S. rochei NRRL B- $2410^{\top}$ and S. naganishii NBRC $12892^{\top}$.

The genome analysis showed the $\mathrm{dDDH}, \mathrm{ANIb}$ and $\mathrm{ANIm}$ values between strain $\mathrm{SBTS} 01^{\top}$ and two related species which shared 16S rRNA gene similarity at $99.0 \%$; S. rochei NRRL B-2410 ${ }^{\top}$ were $29.4,81.1,86.5 \%$, and S. naganishii NBRC $12892^{\top}$ were $26.9,82.1$, $86.9 \%$, respectively. Strain SBTS $01^{\top}$ and its closest neighbour on the phylogenomic tree; S. corchorusii DSM $40340^{\top}$ had the highest dDDH, ANIb and ANIm values at 54.1, 92.6, 94.3\%, respectively. However, strain SBTS01 ${ }^{\top}$ and $S$. corchorusii DSM 40340 ${ }^{\top}$ shared a 16S rRNA gene similarity of only $97.0 \%$. Based on the previous report, the cutoff value at the species level was evaluated at $98.7 \%$ (Stackebrandt and Ebers 2006). Therefore, strain $\mathrm{SBTS}^{\top}{ }^{\top}$ and this type strain belonged to different species. Hence, there is no requirement to compare physiological and biochemical characteristics between strain $\mathrm{SBTS} 01^{\top}$ and this type strain. According to Richter and Rosselló-Móra (2019), the species delineation should have ANI values cut off lower than 95-96\% and dDDH values were lower than the threshold of $70 \%$ used to define species level (Meier-Kolthoff et al. 2013; Chun et al. 2018). Based on the genome comparison, strain $\mathrm{SBTS}^{\top}{ }^{\top}$ is a novel species of the genus Streptomyces.

\section{Genome comparison of strain W18L9 ${ }^{\top}$}

The draft genome sequence of strain $\mathrm{W} 18 \mathrm{~L} 9^{\top}$ was $10.13 \mathrm{Mb}$ with DNA G+C content determined by in silico genome sequence as $70.9 \mathrm{~mol} \%$. The phylogenetic tree based on TYGS revealed that strain W18L9 ${ }^{\top}$ was placed in the same species cluster as its closest neighbour, S. shenzhenensis DSM $42034^{\top}$ but in a different subspecies cluster (Fig. S2). The genome analysis showed the $\mathrm{dDDH}, \mathrm{ANIb}$ and ANIm values of the draft genome between strain W18L ${ }^{\top}$ and its related species, S. shenzhenensis DSM $42034^{\top}$ being $72.5,95.1,97.0 \%$ and $S$. hyaluromycini DSM $100105^{\top}$ being $44.1,88.8,92.4 \%$, respectively. The ANIb, ANIm and dDDH between strain W18L9 ${ }^{\top}$ and the closest type strain S. shenzhenensis DSM $42034^{\top}$ were higher than $95-96 \%$ for ANI values (Richter and Rosselló-Móra 2009) and dDDH value was higher than the threshold of 70\% used to define species delineation (Meier-Kolthoff 
et al. 2013; Chun et al. 2018). Based on these data, strain $\mathrm{W} 18 \mathrm{~L} 9^{\top}$ belonged to the same species of $S$. shenzhenensis DSM $42034^{\top}$. According to Nouioui et al. (2018), dDDH values between 70 and $79 \%$ defined subspecies delineation. Based on the dDDH value between strain $\mathrm{W} 18 \mathrm{~L} 9^{\top}$ and $S$. shenzhenensis DSM $42034^{\top}$ at $72.5 \%$ and the position at different subspecies clusters on the phylogenomic tree, strain $\mathrm{W} 18 \mathrm{~L} 9^{\top}$ belonged to the same species of $S$. shenzhenensis DSM $42034^{\top}$ but it was defined as a novel subspecies.

\section{Chemotaxonomic characteristics}

The $L L$-isomer of DAP was detected in both strains SBTS $01^{\top}$ and $\mathrm{W} 18 \mathrm{~L} 9^{\top}$. The whole-cell sugars of strain SBTS01 ${ }^{\top}$ contained galactose, glucose and mannose and strain $\mathrm{W} 18 \mathrm{~L} 9^{\top}$ contained galactose, glucose, mannose and xylose. The polar lipids of strain SBTS $01^{\top}$ contained phosphatidylethanolamine (PE), phosphatidylinositol (PI), three aminoglycolipids and one glycolipid and strain W18L9 ${ }^{\top}$ contained phosphatidylethanolamine (PE), phosphatidylinositol (PI), six glycolipids, one aminolipid, and four unknown lipids which correspond to phospholipid type II (Lechevalier et al. 1977) (Fig. S3).

The major menaquinones of strains SBTS01 ${ }^{\top}$ and $\mathrm{W} 18 \mathrm{~L} 9^{\top}$ were MK-9 $\left(\mathrm{H}_{6}\right)$ and MK-9 $\left(\mathrm{H}_{8}\right)$. The major cellular fatty acids (more than $10 \%)$ of strain SBTS01 ${ }^{\top}$ were identified as anteiso- $\mathrm{C}_{15: 0}(26.6 \%)$, iso- $\mathrm{C}_{16: 0}(19.1 \%)$ and anteiso- $\mathrm{C}_{17: 0}(19.1 \%)$ which were the same pattern with the closest type strains; $S$. rochei NRRL B-2410 ${ }^{\top}$ (Table 1). The major fatty acids of strain W18L $9^{\top}$ (more than $10 \%$ ) were anteiso- $\mathrm{C}_{15: 0}(21.8 \%)$, anteiso- $\mathrm{C}_{17: 0}(20.9 \%)$ and iso- $\mathrm{C}_{16: 0}(18.5 \%)$

and which were the same pattern with the closest type strain; S. shenzhenensis DSM $42034^{\top}$ (Table S2).

\section{Phenotypic and physiological characterization}

\section{Strain SBTS01 ${ }^{\top}$}

The colony morphology of strain SBTS $01^{\top}$ is described in Table S3. Strain SBTS01 ${ }^{\top}$ showed morphological characteristics with well-developed substrate mycelium and aerial mycelia on most media used. Melanin pigment was produced on ISP 7. Electron micrographs showed that strain SBTS01${ }^{\top}$ formed round rod-shaped spores with spiny surface and spore chains in loop forms (approximately 1 micron length $\mathrm{x} 1$ micron diameter) (Fig. 2A). The physiological properties of strain SBTS01 ${ }^{\top}$ and its closest type strain; S. rochei NRRL B- $2410^{\top}$ were different. Strain SBTS01 ${ }^{\top}$ could assimilate benzoate and tartrate and grow at $\mathrm{NaCl} 5 \%(\mathrm{w} / \mathrm{v})$ but the closest type strain could not assimilate these compounds and could grow weakly at this salt concentration. Also, strain SBTS $01^{\top}$ could grow weakly at $45^{\circ} \mathrm{C}$ and produce melanin pigment on ISP 7 but the type strain could not. On the other hand, the type strain could hydrolyze L-tyrosine and xanthine but strain SBTS $01^{\top}$ could not (Table 1).

\section{Strain W18L9 $9^{\top}$}

The colony morphology of strain W18 $\mathrm{Lg}^{\top}$ is described in Table S3. Strain W18L9 ${ }^{\top}$ showed morphological characteristics with welldeveloped substrate mycelia and aerial mycelia on most media used. No melanin pigment was observed on ISP 7. Electron micrographs showed that strain W18L9 ${ }^{\top}$ formed oval rod-shaped spores (approximately 1.5 micron length $\mathrm{x} 1$ microns diameter) with warty surface and formed spore chains in loops (Fig. 2B). The physiological properties of strain W18L $9^{\top}$ and its closest type strain, S. shenzhenensis DSM $42034^{\top}$ were different. Strain $\mathrm{W} 18 \mathrm{~L} 9^{\top}$ could assimilate maltose, hydrolyze urea, assimilate tartrate and could grow at $15^{\circ} \mathrm{C}$ and $\mathrm{pH} 10$ but the type strain could not. On the other hand, the type strain could hydrolyze hippurate and grow weakly at $5 \% \mathrm{NaCl}(\mathrm{w} / \mathrm{v})$ but strain $\mathrm{W} 18 \mathrm{~L} 9^{\top}$ could not (Table 2).

Based on the results of polyphasic study, strain $\mathrm{SBTS} 01^{\top}$ is proposed as a representative of a novel species of the genus Streptomyces named Streptomyces spinosus sp. nov. and strain $\mathrm{W}_{18 \mathrm{~L}} \mathrm{~g}^{\top}$ is proposed as a novel subspecies of Streptomyces shenzenensis DSM $42034^{\top}$ named Streptomyces shenzenensis subsp. endophyticus subsp. nov.

\section{In vitro antibacterial and antifungal activities}


Strains SBTS $01^{\top}$ and $\mathrm{W} 18 \mathrm{~L} 9^{\top}$ showed strong and moderate activity against a bacterial rice pathogen; Xoo PXO 86, respectively. Strains SBTS01 ${ }^{\top}$ and $W 18 L 9^{\top}$ showed moderate and strong activity against $P$. grisea BRIP 61689, respectively. These results were obtained by the dual culture method. Both strains showed strong activity against S. aureus ATCC 29213 and MRSA 03120385 on both dual culture and agar extraction methods. The antifungal assay against other fungal pathogens was tested by using only a dual culture method. Strain SBTS01 ${ }^{\top}$ showed weak activity against $R$. solani AG8 while strain $\mathrm{W} 18 \mathrm{~L} 9^{\top}$ had strong activity against this fungus. Both strains showed moderate activity against a rice fungus; $C$. lunata BCC 15558 . Strains SBTS $01^{\top}$ and $\mathrm{W}^{18 \mathrm{~L} 9^{\top}}$ showed moderate and weak activity against $H$. oryzae DOAC 1570 , respectively (Table 3 ). HPDA was the best medium for antimicrobial activity of both strains tested by dual culture and agar extraction methods. HPDA and ISP 2 contained 10 and $4 \mathrm{~g}$ of dextrose, respectively. Then, it was not an effect of carbon catabolite regulation (CCR) which is a regulatory mechanism that limits production due to a negative effect applied by high concentrations of dextrose (Sanchez and Demain 2002). ISP 2 contained malt extract and yeast extract at 10 and $4 \mathrm{~g} / \mathrm{L}$ while HPDA comprised potato infusion. It was reported that some nitrogen sources may decrease antibiotic production in different microorganisms including Streptomyces (Rafieenia 2013). Based on the result of antibiotic production, it is necessary to select at least two media with different compositions to screen for antimicrobial activity.

\section{Plant growth promoting traits}

Only strain W18L9 ${ }^{\top}$ could grow on DF agar with ACC deaminase as a nitrogen source, fix nitrogen on NFB medium, solubilize inorganic phosphate and produce cellulase enzyme (Table 4). Strain SBTS01 ${ }^{\top}$ had negative results for these tests. Both strains could not produce HCN but they could produce siderophore (hydroxymate type). Strains SBTS01 ${ }^{\top}$ and W18L9 ${ }^{\top}$ produced IAA at 71 and $150 \mathrm{ug} / \mathrm{mL}$ and produced cytokinins at 0.165 and $0.169 \mathrm{mg} / \mathrm{L}$, respectively (Table 4).

\section{Secondary metabolites and biosynthesis gene cluster prediction}

There were many BGCs of strains SBTS $01^{\top}$ and $\mathrm{W} 18 \mathrm{~L} 9^{\top}$ derived from "antiSMASH" database. There were six groups of metabolites; terpene, type 1 polyketide synthase (T1PKS), type2 PKS (T2PKS), type3 PKS (T3PKS), Non-ribosomal peptide synthetase cluster (NRPS), lanthipeptide cluster and other compounds (Table 5). Both strains contained terpene clusters; geosmin and albaflavenone (100\% similarity). Geosmin is recognized as an earthy odor that was generally produced by many genera of actinobacteria including Streptomyces species (Jiang et al. 2007). Albaflavenone, a tricyclic sesquiterpene antibiotic, which was produced by many Streptomyces sp. possessed an antibacterial activity (Moody et al. 2011). Also, strains SBTS01 ${ }^{\top}$ and $\mathrm{W} 18 \mathrm{~L} 9^{\top}$ contained gene clusters encoding hopene at 76 and $96 \%$ similarity, respectively. Hopene is a precursor for producing bioactive hopanoids, a group of pentacyclic triterpenoids such as diploterol which is toxic to mouse leukemia cells (Schmerk et al. 2015; Sohlenkamp and Geiger 2016). Strain SBTS01 ${ }^{\top}$ contained isorenieratene (62\% similarity) which is a carotenoid light- harvesting pigment produced by green sulfur bacteria; Chlorobium spp. There were some reports of isorenieratene biosynthesis by actinobacteria but the function of this compound is still unknown and it may relate to blue or UV light resistance (Maresca et al. 2008). Strain SBTS01 ${ }^{\top}$ comprised T1PKS cluster; sceliphrolactam and antimycin (92 and $93 \%$ similarity). Sceliphrolactam, a macrocyclic lactam exhibited antifungal activity against amphotericin B-resistant Candida albicans (Oh et al. 2011). Antimycin is produced by many strains of Streptomyces $s p$. and it was reported that the antimycin A family possessed effective antifungal, insecticidal, nematocidal and anticancer activities (Ondrejičková et al. 2016). Also, Nakayama et al. (1956) reported the activity of this compound against rice blast fungus which correlated to this study in which strain $\mathrm{SBTS} 01^{\top}$ showed moderate activity against this pathogen in vitro. Moreover, strain SBTS01${ }^{\top}$ contains T2PKS cluster; lugdunomycin ( $40 \%$ similarity). Lugdunomycin is an angucycline-derived molecule containing a heptacyclic ring system and represents a novel subclass of aromatic polyketides. It was reported that this compound had antimicrobial activity against the Gram-positive Bacillus subtilis 168 (Wu et al. 2019). As strain SBTS $01^{\top}$ had low similarity at $40 \%$ with lugdunomycin gene cluster, it has a possibility to produce a novel compound of aromatic polyketides. Furthermore, strain $\mathrm{SBTS} 01^{\top}$ contained a RiPP: Lanthipeptide cluster;

informatipeptin (57\% similarity). It was stated that microorganisms containing a RiPP: Lanthipeptide clusters are likely to produce novel bioactive compounds (Repka et al. 2017). Strain SBTS01 ${ }^{\top}$ comprised NRPS, ladderane cluster; ishigamide (100\% similarity), a polyene-containing amide (Du et al. 2016). Furthermore, strain SBTS01 ${ }^{\top}$ comprised gene cluster, alkaloid; anisomycin (61\% similarity), a pyrrolidine antibiotic containing a variety of activities. It was reported that anisomycin can block peptide bond 
formation and showed potential against pathogenic protozoa and fungi. This compound can induce cell cycle apoptosis and activate the c-Jun N-terminal kinases (JNKs) signal pathway to exhibit potential antitumor activity (Shen et al. 2019).

In correlation with the genome data mining, strain $\mathrm{SBTS} 01^{\top}$ also showed good activity against Xoo PXO 86, S. aureus ATCC 29213 and MRSA 03120385 in which this strain may be likely to produce novel antibiotics. Finally, strain SBTS $01^{\top}$ contained a gene cluster, melanin (71\% similarity). Melanin pigment produced from microorganisms could help to resist chemicals and oxidizing agents, thermal, and biochemical stresses (El-Naggar and El-Ewasy, 2017). This gene finding correlated with in vitro study in which strain $\mathrm{SBTS} 01^{\top}$ produced melanin pigment on ISP 7. In addition, this strain contained a gene cluster encoding spore pigment which benefits bacteria to tolerate UV and other environmental stresses (El-Naggar and El-Ewasy, 2017). As strain SBTS01 ${ }^{\top}$ was isolated from a rice paddy field which applied many pesticides such as fungicide, herbicide, and insecticide, this strain tended to adapt for resisting to survive from chemicals (personal communication with Dr. Ronnachai Changsri, a researcher at rice department, Thailand).

Strain W18L9 $9^{\top}$ comprised a variety of BGCs. This strain contained T1PKS clusters; rhizomide A, B and C (100\% similarity). Rhizomide A, B and C showed weak antitumor activity against several human tumor cells lines $\left(\mathrm{IC}_{50} 34 \mu \mathrm{M}\right.$ to $\left.96 \mu \mathrm{M}\right)$. It was reported that rhizomide $A$ showed protective activity against cucumber downy mildew (Pseudoperonospora cubenis), Staphylococcus aureus and Bacillus subtilis (Wang et al. 2018). Strain W18L9 ${ }^{\top}$ contained T2PKS cluster; curamycin (57\% similarity), a polyketide antibiotic produced by Streptomyces curacoi which could inhibit S. aureus (Galmarini and Deulofeu 1961). Strain W18L9 ${ }^{\top}$ contained T3PKS clusters; germicidin and feglymycin (100 and 47\% similarity). Germicidin was the auto regulative inhibitor of spore germination in the genus Streptomyces(Petersen et al. 1993).

Feglymycin, a novel peptide antibiotics was reported to inhibit the replication of the human immunodeficiency virus (HIV) in vitro (Vértesy et al. 1999). Furthermore, strain W18L9 ${ }^{\top}$ comprised NRPS/NRPS like clusters; xenotetrapeptide, tolaasin I / tolaasin F (100 and 50\% similarity). The novel xenotetrapeptides were nonribosomally synthesized peptides which have been still unknown function produced from Xenorhabdus nematophila, bacteria reside as endosymbionts in the foreguts of soil nematodes in genus Steinernema (Khandelwal and Banerjee-Bhatnagar 2003). In correlation with the genome data mining, strain W18L $9^{\top}$ showed good activity against S. aureus ATCC 29213, MRSA 03120385, P. grisea BRIP 61689 and $R$. solani AG8 in vitro. The properties of strain $\mathrm{W} 18 \mathrm{~L} 9^{\top}$ to inhibit rice pathogens are correspondent with its ecophysiology inside rice tissue which benefits plant to inhibit pathogens.

In addition, the result showed that both strains contained gene cluster to synthesize siderophore, desferrioxamine $E$ which plays an important role in the growth and development of Streptomyces (Codd et al. 2018). It was correspondent with the result of PGP traits of both strains which could produce siderophore (hydroxymate type) in vitro.

\section{In silico gene prediction}

Other genes of strains $\mathrm{SBTS} 01^{\top}$ and $\mathrm{W} 18 \mathrm{~L} 9^{\top}$ encoding other bioactive compounds relating to plant growth promoting, degradable enzymes and bioremediation were scanned. The result showed that these strains contained a variety of genes encoding drought tolerant and stress response proteins and iron uptake protein relating to plant growth promoting properties (Table S4 and S5). For drought and salt tolerant proteins, both strains contained genes encoding ectoine production, glycine betaine/L-proline transporter, glycine, betaine and proline production, $\mathrm{Ca}^{2+}: \mathrm{H}^{+}$antiporter and chloride channel protein. Only strain SBTS01 ${ }^{\top}$ contained sodium solute symporter and potassium channel family protein which can support plants to tolerate salt stress (Horn et al. 2006).

Only strains W18L9 ${ }^{\top}$ contained the gene encoding ACC deaminase which supports plants in stress condition such as drought, flooding, nutrient starvation, temperature, salt and oxidative stresses including toxic agents (Gupta and Pandey 2019). Strain W18 $\mathrm{L}^{\top}$ contained genes relating to nitrogen fixation; ADP-ribosyl-dinitrogen reductase. These genes correlated with the results in which this strain could produce ACC deaminase and had ability to fix nitrogen in vitro. Also, the gene encoding indole-3-glycerol phosphate synthase relating to indole acetic acid (IAA) production was detected in the genome of strain SBTSO $1^{\top}$. IAA is a derivative of a plant hormone, auxin which promotes plant growth and support plant growth in salt stress condition (Keswani et al. 2020). In correlation with this gene finding, strain SBTS $01^{\top}$ and $\mathrm{W} 18 \mathrm{~L} 9$ were able to produce IAA in vitro. Furthermore, there were 
many genes encoding universal stress proteins (usp) which were detected in both genomes. It was reported that bacteria containing usp genes play a role in maintaining internal and external protection mechanisms in biotic and abiotic stresses (Kim et al. 2012). Strain $\mathrm{W} 18 \mathrm{~L} 9^{\top}$ and strain $\mathrm{SBTS} 01^{\top}$ comprised genes encoding exopolyphosphatase and inorganic pyrophosphatase while strain $\mathrm{SBTSO}^{\top}$ also contained phosphatase and alkaline phosphatase. However, only strain W18L9 ${ }^{\top}$ showed an ability to solubilize inorganic phosphate in vitro. From this result, it can conclude that strain SBTS $01^{\top}$ contained cryptic genes which required gene induction to express phosphate solubilization. The rice paddy field which plant source collected is in Suvannabhum district, Roiet province. This area is known as Thug Gura Ronghai which contains poor soil, fine-loamy soil type and moderate salt (EC 4-8 dS/m). The subsoil contains a lot of rock salt and potash (Sahunalu 2003). In correlation with the ecophysiology, strains SBTS $01^{\top}$ and $\mathrm{W} 18 \mathrm{~L} 9^{\top}$ contained genes encoding plant growth promoting traits to promote rice growth in poor soil and salinity condition.

Strain SBTS $01^{\top}$ and W18L9 $9^{\top}$ comprised many genes encoding beneficial enzymes which can be applied in a variety of industries. There were several types of enzymes; alpha-N-arabinofuranosidase, amylase, $\beta$-glucosidase, $\beta$-xylosidase, and $\beta$-xylanase which could degrade hemicellulose, polysaccharide, or plant residue to obtain fermentable sugars for applying in bioethanol production (Podkaminer et al. 2012). Genes encoding chitinase were also detected in both strains. It was reported that bacteria producing chitinolytic enzymes could inhibit fungal pathogens by degrading fungal cell walls and degrading waste containing chitin (Brzezinska et al. 2014). Also, these two strains contained genes encoding lipase and various types of proteases which can be applied in many industries such as detergent, food and feed additive, leather and textile industries.

Genes encoding proteins in bioremediation were also mined. Strain $\mathrm{W} 18 \mathrm{~L} 9^{\top}$ contained five genes encoding xenobiotic degradable enzymes; alkanesulfonate monooxygenase, nitroalkane oxidase, nitroreductase, epoxide hydrolase and phenol 2-monooxygenase. Alkanesulfonate monooxygenase participates in alkanesulfonate degradation. Nitroalkane oxidase relates to nitroalkane degradation in which nitroalkane compounds are used as solvents and explosive compounds and as herbicide and pesticide agents in agriculture and 2-nitropropane was reported as a carcinogen (Li et al. 2008). Nitroreductase can reduce pollutants such as 2,4-dinitrotoluene and 2,4,6-trinitrotoluene, as well as key chemical intermediates, 3-nitrophthalimide, 4-nitrophthalimide and 4nitro-1,8-naphthalic anhydride. Also, strain W18L $9^{\top}$ contained gene encoding tellurium resistance protein. Gene encoding a latex clearing protein was detected in this strain which can apply to degrade waste containing rubber such as used gloves and tires. This will be valuable to degrade xenobiotic waste in the environment. As stated above, the rice paddy field was contaminated with many pesticides applied in the area for many years. Strain $\mathrm{W} 18 \mathrm{~L} 9^{\top}$ may adapt to survive in the environment contaminated with these compounds and contains genes encoding enzymes for degrading pesticides.

Strain $\mathrm{SBTS}^{\top}{ }^{\top}$ contained genes encoding aldehyde dehydrogenase family protein, 2-nitropropane dioxygenase and haloacid dehalogenase type II. This strain also contained genes encoding ion detoxification protein; selenium-binding protein, tellurium resistance protein,

and arsenate reduction. Gene encoding mycoredoxin which plays an important role in arsenic resistance was also detected in the genome of strain SBTS01 ${ }^{\top}$ (Mourenza et al. 2019).

For anticancer compound, strain W18 $\mathrm{L}^{\top}$ comprised gene encoding immune checkpoint inhibitors (ICls) which are monoclonal antibodies that block inhibitors of T-cell activation and function. The ICls have potential effects on more than 14 different cancers which were reported to have effects in some patients for more than 5 years (20\% - 40\%; 5 -year survival rate in patients with melanoma) (Johnson et al. 2018). Based on the genome data mining, strain W18L $9^{\top}$ has the potential to produce anti-HIV and anticancer compounds which will be fruitful to study this strain in-depth for novel bioactive compounds in the future.

\section{Conclusion}

In conclusion, strains $\mathrm{SBTS} 01^{\top}$ and $\mathrm{W} 18 \mathrm{~L} 9^{\top}$ can be differentiated from other species of the genus Streptomyces by ANI and dDDH values, a phylogenetic tree of the genome, and their phenotypic and chemotaxonomic features. The name, Streptomyces spinosus is proposed for this novel species and Streptomyces shenzenensis subsp. endophyticus is proposed for this novel subspecies. These strains could produce antibiotics to inhibit bacterial pathogens, X. oryzae pv. oryzae PXO 86, S. aureus ATCC 29213, MRSA

Page $11 / 24$ 
03120385 and a fungal pathogen, $P$. grisea BRIP 61689. Strain W18L $9^{\top}$ could solubilize inorganic phosphate, produce ACC deaminase, produce cellulase enzyme and fix nitrogen. Both strains could produce siderophore, IAA and cytokinin. Genome mining revealed that these strains have the potential to produce novel metabolites. The genome data mining of these strains comprised several genes relating to plant growth promotion under stress conditions. Genome mining correlated with properties of these strains in vitro. Also, both strains contained versatile genes encoding beneficial enzymes and xenobiotic degradation which can be used in many industries and remedy polluted environments for further study.

\section{Description of Streptomyces spinosus sp. nov.}

Streptomyces spinosus (spi.no'sus. L. masc. adj. spinosus, spiny, referring to the spiny spore surface).

Gram stain-positive, aerobic, catalase positive. Cells grow between 15 and $45^{\circ} \mathrm{C}$ but grow well at $27^{\circ} \mathrm{C}$. Cells grow between pH 5.0 and 10.0 but grow well between $\mathrm{pH} 7.0$ and pH 8.0. Cells cannot grow in the presence of $10 \%(\mathrm{w} / \mathrm{v}) \mathrm{NaCl}$. Substrate mycelium develops well on all the media used with light brown color and produces dark green spore on all media used. This strain produces melanin pigments on ISP 7. The mycelium is extensively branched and forms loop spore chains. A rod-shaped spore (1 um diameter $x 1 \mu \mathrm{m}$ length) is observed with a spiny surface. Strain SBTS01${ }^{\top}$ produces acid from cellobiose, fructose, galactose, glucose, maltose, mannose, myo-inositol, mannitol, rhamnose, ribose, trehalose, xylose, arabinose, salicin, raffinose and sucrose but not from dulcitol and sorbitol. This strain can hydrolyze esculin, urea, adenine, starch, skim milk but not hippurate, $L$-tyrosine and xanthine. Strain SBTS01${ }^{\top}$ cannot use pyridine, toluene, phenol and benzene as sole carbon sources. This strain can assimilate acetate, benzoate, malate, tartrate, citrate and propionate. Whole-cells contain $L L$-diaminopimelic acid in its peptidoglycan and galactose, glucose and mannose as whole-cell sugars. Polar lipids are phosphatidylethanolamine (PE) and phosphatidylinositol (PI). MK-9 $\left(\mathrm{H}_{6}\right)$ and MK-9 $\left(\mathrm{H}_{8}\right)$ are predominant menaquinones. Major cellular fatty acids are anteiso- $\mathrm{C}_{15: 0}$, iso- $\mathrm{C}_{16: 0}$ and anteiso$\mathrm{C}_{17: 0}$. The DNA G+C content of the type strain is $72.5 \%$.

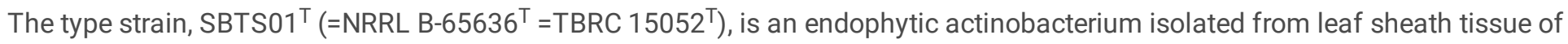
Jasmin rice (Oryza sativa KDML 105) grown at rice paddy field, Roiet province, Thailand. The GenBank/EMBL/DDBJ accession numbers for the 16S rRNA gene sequence and the whole genome shotgun project of strain SBTS01 ${ }^{\top}$ are MZ901362 and JAINRC000000000, respectively. Strain SBTS $01^{\top}$ can strongly inhibit Xanthomonas oryzae pv. oryzae PXO 86, Staphytococcus aureus ATCC 29213 and Methicillin Resistant Staphytococcus aureus 03120385 in vitro.

Description of Streptomyces shenzenensis subsp. shenzenensis

Streptomyces shenzenensis subsp. shenzenensis (shen.zhen.en'sis. N.L. masc. adj. shenzhenensis, pertaining to Shenzhen, China, from where the strain was isolated)

The description is as given for Streptomyces shenzenensis (HU et al. 2011) with the following modification. The $\mathrm{G}+\mathrm{C}$ content of the type-strain genome determined by in silico approach is $71.4 \%$, its approximate size $10.64 \mathrm{Mbp}$, its GenBank deposit JAJONF000000000. Hu et al. (2011) deposited 16S rRNA gene sequence of this strain as GenBank accession number HQ660226.

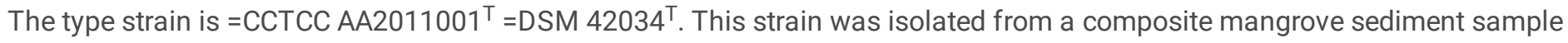
collected in Shenzhen, China.

Description of Streptomyces shenzenensis subsp. endophyticus subsp. nov.

Streptomyces shenzenensis subsp. endophyticus (en.do.phy'ti.cus. Gr. pref. endo, within; Gr. neut. n. phyton, plant; L. fem. suff. ica, adjectival suffix used with the sense of belonging to; N.L. masc. adj. endophyticus within plant, endophytic, pertaining to isolation of the type strain from plant tissues).

Cells grow between 15 and $37^{\circ} \mathrm{C}$ but grow well at $27^{\circ} \mathrm{C}$. Cells grow between pH 5.0 and 10.0 but grow well between pH 7 and pH 8.0. Cells cannot grow in the presence of $5 \%(\mathrm{w} / \mathrm{v}) \mathrm{NaCl}$. Substrate mycelium develops well on all the media used with yellow color and cells produce light gray spores on all media used. This strain cannot produce melanin pigments on ISP 7. The mycelium is extensively branched and forms loop spore chains. A rod-shaped spore (1 um diameter x $1.5 \mu \mathrm{m}$ length) is observed with a warty surface. Strain W18L9 $9^{\top}$ produces acid from cellobiose, fructose, galactose, glucose, mannose, myo-inositol, mannitol, ribose, 
sucrose, trehalose, arabinose, maltose, raffinose, rhamnose, xylose but not dulcitol, salicin and sorbitol. Strain W18L ${ }^{\top}$ can hydrolyze starch, urea, skim milk but not xanthine, esculin, hippurate, L-tyrosine and adenine. They could assimilate benzoate, malate, tartrate, acetate, citrate and propionate. This strain cannot use phenol, pyridine, toluene and benzene as sole carbon source. Whole-cells contain

LL-diaminopimelic acid in its peptidoglycan and galactose, glucose, mannose and xylose as whole-cell sugars. Polar lipids are phosphatidylethanolamine(PE) and phosphatidylinositol $(\mathrm{PI})$. MK-9 $\left(\mathrm{H}_{6}\right)$ and $\mathrm{MK}-9\left(\mathrm{H}_{8}\right)$ are predominant menaquinones. Major

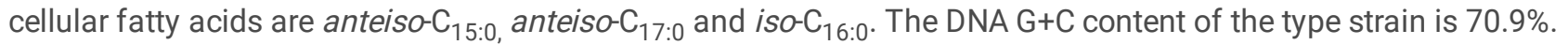

The type strain, $\mathrm{W} 18 \mathrm{~L} 9^{\top}\left(\mathrm{NRRL} B-65635^{\top}=\mathrm{TBRC}^{15051^{\top}}\right)$, is an endophytic actinobacterium isolated from leaf tissue of Jasmin rice (Oryza sativa KDML 105) grown at rice paddy field,

Roiet province, Thailand. The GenBank/EMBL/DDBJ accession numbers for the 16S rRNA gene sequence and the whole genome shotgun project of strain W18 L9 ${ }^{\top}$ are MZ901363 and JACBWY000000000, respectively. Strain W18L9 ${ }^{\top}$ can strongly inhibit Staphytococcus

aureus ATCC 29213 and Methicillin Resistant Staphytococcus aureus 03120385, Pyricularia grisea BRIP 61689 and Rhizoctonia solani AG8 in vitro.

\section{Declarations}

\section{Acknowledgements}

This work was financially supported by Mahasarakham University, Thailand (Grant Number 640219/2564). We are very grateful to MS. Kewalee Prompiputtanaporn, Suranaree Electron Microscope, Suranaree University of Technology, Thailand for the visualization of SEM. We are very grateful to Prof. Aharon Oren for kind checking the correction of new species/subspecies names.

\section{Author contribution statement}

OK planned the experiments, carried out the experimental work, analyzed all data and prepared the draft manuscript. SS did the technician works for physiological and morphological study. CS and NC extracted and analyzed FAMEs. CS extracted genomic DNA of strain SBTS $01^{\top}$ and S. shenzhenensis DSM $42034^{\top}$ for whole genome sequence. TC analyzed menaquinones by using LCMS. CF proofed the manuscript and provided the facilities for conducting the research.

\section{Declaration of Competing interest}

The authors report no declarations of interest.

\section{Ethical statement}

This article does not contain any studies with human participants or animal experiments by any of the authors.

\section{References}

1. Abdelmohsen UR, Grkovic T, Balasubramanian S, Kamel MS, Quinn RJ, Hentschel U (2015)

2. Elicitation of secondary metabolism in actinomycetes.Biotechnol Adv33:798-811

3. Ahmad K, Bhuiyan JAM (1958) A new antifungal Streptomyces species. Streptomyces corchorusii. Pak J Biol Sci 1:137-143

4. Atlas RM, Parks LC (1993) In: Parks LC (ed) Handbook of Microbiological Media

5. Press CRC Boca Raton

6. Bakker AW, Schippers B (1987) Microbial cyanide production in the rhizosphere in relation to potato yield reduction and Pseudomonas spp. mediated plant growth-stimulation. Soil Biol Biochem 19:451-457 
7. Baldani Jl, Caruso L, Baldani VLD, Goi SR, Döbereiner J (1997) Recent advances in BNF with non-legume plants. Soil Biol Biochem 29:911-922

8. Barnett S, Ballard RA, Franco CMM (2019) Field assessment of microbial inoculants to control Rhizoctonia root rot on wheat. Biol Control 132:152-160

9. Berger J, Jampolsky LM, Goldberg MW (1953) In: Waksman SA (ed) Lechevalier HA Guide to the classification and identification of the actinomycetes and their antibiotics. The Williams and Wilkins Co., Baltimore, pp 1-246

10. Blin K, Shaw S, Kloosterman AM, Charlop-Powers Z, Van Weezel GP, Medema MH, Weber T (2021) antiSMASH 6.0: Improving cluster detection and comparison capabilities. Nucleic Acids Res 49:W29-W35

11. Bousfield IJ, Keddie RM, Dando TR, Shaw S (1985) Simple rapid methods of cell wall analysis as an aid in the identification of aerobic coryneform bacteria. Chem Method Bact Syst Tech Ser 20:221-236

12. Brzezinska MS, Jankiewicz U, Burkowska A, Walczak M (2014) Chitinolytic microorganisms and their possible application in environmental protection. Curr Microbiol 68:71-81

13. Castagno L, Estrella M, Sannazzaro A, Grassano A, Ruiz O (2011) Phosphate-solubilization mechanism and in vitro plant growth promotion activity mediated by Pantoea eucalypti isolated from Lotus tenuis rhizosphere in the Salado River Basin (Argentina). J Appl Microbiol 110:1151-1165

14. Chun J, Oren A, Ventosa A, Christensen H, Arahal DR, da Costa MS, Rooney AP, Yi H, Xu X-W, De Meyer S, Trujillo ME (2018) Proposed minimal standards for the use of genome data for the taxonomy of prokaryotes. Int J Syst Evol Microbiol 68:461466

15. Codd R, Richardson-Sanchez T, Telfer TJ, Gotsbacher MP (2018) Advances in the chemical biology of desferrioxamine B. ACS Chem Biol 13:11-25

16. Conn VM, Walker AR, Franco CMM (2008) Endophytic actinobacteria induce defense pathways in Arabidopsis thaliana. Mol Plant Microbe Interact 21:208-218

17. Coombs JT, Franco CMM (2003) Isolation and identification of actinobacteria from surface-sterilized wheat roots. Appl Environ Microbiol 69:5603-5608

18. Du D, Katsuyama Y, Onaka H, Fujie M, Satoh N, Shin-Ya K, Ohnishi Y (2016) Production of a novel amide-containing polyene by activating a cryptic biosynthetic gene cluster in Streptomyces sp. MSC090213JE08. ChemBioChem 17:1464-1471

19. El-Naggar NE, El-Ewasy SM (2017) Bioproduction, characterization, anticancer and antioxidant activities of extracellular melanin pigment produced by newly isolated microbial cell factories Streptomyces glaucescens NEAE-H. Sci Rep 7:42129

20. Farris JS (1972) Estimating phylogenetic trees from distance matrices. Am Nat 106:645-667

21. Felsenstein J (1985) Confidence limits on phylogenies: an approach using the bootstrap. Evolution 39:783-791

22. Galmarini OL, Deulofeu V (1961) Curamycin-I. isolation and characterization of some hydrolysis products. Tetrahedron15:7686

23. Gao Y, Ning Q, Yang Y, Liu Y, Niu S, Hu X, Pan H, Bu Z, Chen N, Guo J, Yu J, Cao L, Qin P, Xing J, Liu B, Liu X, Zhu Y (2021) Endophytic Streptomyces hygroscopicus OsiSh-2-mediated balancing between growth and disease resistance in host rice. mBio 12:e0156621

24. Glickmann E, Dessaux Y (1995) A critical examination of the specificity of the Salkowski reagent for indolic compounds produced by phytopathogenic bacteria. Appl Environ Microbiol 61:793-796

25. Gordon RE, Barnett DA, Handerhan JE, Pang CH (1974) Nocardia coeliaca, Nocardia autotrophica, and the nocardin strain. Int J Syst Bacteriol 24:54-63

26. Gupta S, Pandey S (2019) ACC deaminase producing bacteria with multifarious plant growth promoting traits alleviates salinity stress in French bean (Phaseolus vulgaris) plants. Front Microbiol 10:1506

27. Harunari E, Hamada M, Shibata C, Tamura T, Komaki H, Igarashi Y Streptomyces hyaluromycini sp. nov., isolated from a tunicate (Molgula manhattensis).J Antibiot69:15-163

28. Hasegawa T, Takisawa M, Tanida S (1983) A rapid analysis for chemical grouping of aerobic actinomycetes. J Gen Appl Microbiol 29:319-322 
29. Hayakawa M, Nonomura H (1987) Humic acid-vitamin agar, a new medium for the selective isolation of soil actinomycetes. $J$ Ferment Technol 65:501-509

30. Horn C, Sohn-Bo L, Breed J, Welte W, Schmitt L, Bremer E (2006) Molecular determinants for substrate specificity of the ligandbinding protein OpuAC from Bacillus subtilis for the compatible solutes glycine betaine and proline betaine. J Mol Biol 357:592-606

31. Hu H, Lin HP, Xie Q, Li L, Xie XQ, Sun M, Hong K (2011) Streptomyces shenzhenensis sp. nov., a novel actinomycete isolated from mangrove sediment. Antonie Van Leeuwenhoek 100:631-637

32. Hussain A, Hasnain S (2009) Cytokinin production by some bacteria: its impact on cell division in cucumber cotyledons. Afr J Microbiol Res 3:704-712

33. Islam F, Roy N (2018) Screening, purification and characterization of cellulase from cellulase producing bacteria in molasses. BMC Res Notes 11:445

34. Jiang J, He X, Cane DE (2007) Biosynthesis of the earthy odorant geosmin by a bifunctional Streptomyces coelicolor enzyme. Nat Chem Biol 3:711-715

35. Johnson DB, Chandra S, Sosman JA (2018) Immune checkpoint inhibitor toxicity in 2018. JAMA 16:1702-1703

36. Jukes TH, Cantor CR (1969) Evolution of protein molecules. In: Munro HN (ed) Mammalian Protein Metabolism. Academic Press, New York, pp 21-132

37. Kaewkla O, Franco CMM (2013) Rational approaches to improving the isolation of endophytic actinobacteria from Australian native trees. Microbial Ecol 65:384-393

38. Kaewkla O, Franco CMM (2017) Streptomyces roietensis sp. nov., an endophytic actinobacterium isolated from the surfacesterilized stem of Jasmine rice, Oryza sativa KDML 105. Int J Syst Evol Microbiol 67:4868-4872

39. Kaewkla O, Franco CMM (2019) Actinomycetospora callitridis sp. nov., an endophytic actinobacterium isolated from the surface-sterilized root of an Australian native pine tree. Antonie Van Leeuwenhoek 112:331-337

40. Kaewkla O, Franco CMM (2021) Genome mining and description of Streptomyces albidus sp. nov., an endophytic actinobacterium with antibacterial potential. Antonie Van Leeuwenhoek 114:539-551

41. Kampapongsa D, Kaewkla O (2016) Biodiversity of endophytic actinobacteria from Jasmine rice (Oryza sativa L. KDML 105) grown in Roi-Et Province, Thailand and their antimicrobial activity against rice pathogen. Ann Microbiol 66:587-595

42. Kämpfer P (2012) Genus I. Streptomyces Waksman and Henrici 1943, 339AL emend. Witt and Stackebrandt 1990, 370 emend. Wellington, Stackebrandt, Sanders, Wolstrup and Jorgensen 1992, 159 In: Whitman WB, Goodfellow M, Kämpfer P, Busse HJ, Trujillo ME, Ludwig W, Suzuki KI, Parte A (eds.) Bergey's Manual of Systematic Bacteriology, 2nd (edn): vol. 4, New York, Springer $1750 \mathrm{pp}$

43. Keswani C, Singh SP, Cueto L, García-Estrada C, Mezaache-Aichour S, Glare TR, Borriss R, Singh SP, Blázquez MA, Sansinenea E (2020) Auxins of microbial origin and their use in agriculture. Appl Microbiol Biotechnol 104:8549-8565

44. Khamna S, Yokota A, Lumyong S (2009) Actinomycetes isolated from medicinal plant rhizosphere soils: diversity and screening of antifungal compounds, indole-3-acetic acid and siderophore production.World J Microbiol Biotechnol25:649655

45. Khandelwal P, Banerjee-Bhatnagar N (2003) Insecticidal activity associated with the outer membrane vesicles of Xenorhabdus nematophilus. Appl Environ Microbiol 69:2032-2037

46. Kim H, Goo E, Kang Y, Kim J, Hwang I (2012) Regulation of universal stress protein genes by quorum sensing and rpoS in Burkholderia glumae. J Bacteriol 194:982-992

47. Komagata K, Suzuki K (1987) Lipid and cell wall analysis in bacterial systematics. Methods Microbiol 19:161-207

48. Kornerup J, Wanscher H (1978) In: Methuen PD (ed) Handbook of colour, 3rd edn. Cox \& Wyman Ltd, Fakenham

49. Kumar S, Stecher G, Li M, Knyaz C, Tamura K (2018) MEGA X: Molecular evolutionary genetics analysis across computing platforms. Mol Biol Evol 35:1547-1549

50. Kurup KV, Schmitt JA (1973) Numerical taxonomy of Nocardia. Can J Microbiol 19.:1035-1048

51. Lechevalier MP, Bievre CD, Lechevalier H (1977) Chemotaxonomy of aerobic actinomycetes: phospholipid composition. Biochem Syst Ecol 5:249-260

Page $15 / 24$ 
52. Lefort V, Desper R, Gascuel O (2015) FastME 2.0: A comprehensive, accurate, and fast distance-based phylogeny inference program. Mol Biol Evol 32:2798-2800

53. Li Y, Zhang J, Tan H (2008) Identification of a nitroalkane oxidase gene: naoA related to the growth of Streptomyces ansochromogenes. Curr Microbiol 57:588-592

54. Luo Y, Cobb RE, Zhao H (2014) Recent advances in natural product discovery. Curr Opin Biotechnol 30:230-237

55. Maresca JA, Romberger SP, Bryant DA (2008) Isorenieratene biosynthesis in green sulfur bacteria requires the cooperative actions of two carotenoid cyclases. J Bacteriol 190:6384-6391

56. Meier-Kolthoff JP, Auch AF, Klenk H-P, Goker M (2013) Genome sequence-based species delimitation with confidence intervals and improved distance functions. BMC Bioinformatics 14:60

57. Meier-Kolthoff JP, Göker M (2019) TYGS is an automated high-throughput platform for state-of-the-art genome-based taxonomy. Nat Commun 10:2182

58. Mingma R, Duangmal K, Thamchaipenet A, Trakulnaleamsai S, Matsumoto A, Takahashi Y (2015) Streptomyces oryzae sp. nov., an endophytic actinomycete isolated from stems of rice plant. J Antibiot 68:368-372

59. Minnikin DE, O'Donnell AG, Goodfellow M, Alderson G, Athalye M, Schaal A, Parlett JH (1984) An integrated procedure for the extraction of bacterial isoprenoid quinones and polar lipids. J Microbiol Methods 2:233-241

60. Moody S, Zhao B, Lei L, Nelson D, Mullins J, Waterman M, Kelly S, Lamb D (2011) Investigating conservation of the albaflavenone biosynthetic pathway and CYP170 bifunctionality in streptomycetes. The FEBS J 279:1640-1649

61. Mourenza Á, Bravo-Santano N, Pradal I, Gil JA, Mateos LM, Letek M (2019) Mycoredoxins are required for redox homeostasis and intracellular survival in the actinobacterial pathogen Rhodococcus equi. Antioxidants 8:558

62. Naik BS, Shashikala J, Krishnamurthy YL (2009) Study on the diversity of endophytic communities from rice (Oryza sativa L.) and their antagonistic activities in vitro. Microbiol Res 164:290-296

63. Nakayama K, Okamoto F, Harada Y (1956) Antimycin A: isolation from a new Streptomyces and activity against rice plant blast fungi. J Antibiot 9:63-66

64. Nei M, Kumar S (2000) Molecular Evolution and Phylogenetics. Oxford university press, New York

65. Nouioui I, Carro L, García-López M, Meier-Kolthoff JP, Woyke T, Kyrpides NC, Pukall R, Klenk HP, Goodfellow M, Göker M (2018) Genome-based taxonomic classification of the phylum actinobacteria. Front Microbiol 9:2007

66. Oh DC, Poulsen M, Currie CR, Clardy J (2011) Sceliphrolactam, a polyene macrocyclic lactam from a wasp-associated Streptomyces sp. Org Lett 13:752-755

67. Ondrejíčková P, Šturdíková M, Hushegyi A, Švajdlenka E, Markošová K, Čertík M (2016) Endophytic Streptomyces sp. AC35, a producer of bioactive isoflavone aglycones and antimycins. $J$ Ind Microbiol Biotechnol 43:1333-1344

68. Parte AC, Sardà Carbasse J, Meier-Kolthoff JP, Reimer LC, Göker M (2020) List of prokaryotic names with standing in nomenclature (LPSN) moves to the DSMZ. Int J Syst Evol Microbiol 70:5607-5612

69. Penrose DM, Glick BR (2003) Methods for isolating and characterizing ACC deaminase-containing plant growth-promoting rhizobacteria. Physiol Plant 118:10-15

70. Pérez-Miranda S, Cabirol N, George-Téllez R, Zamudio-Rivera LS, Fernández FJ (2007) O-CAS, a fast and universal method for siderophore detection. J Microbiol Methods 70:127-131

71. Petersen F, Zähner H, Metzger JW, Freund S, Hummel RP (1993) Germicidin, an autoregulative germination inhibitor of Streptomyces viridochromogenes NRRL B-1551. J Antibiot 46:1126-1138

72. Podkaminer KK, Guss AM, Trajano HL, Hogsett DA, Lynd LR (2012) Characterization of xylan utilization and discovery of a new endoxylanase in Thermoanaerobacterium saccharolyticum through targeted gene deletions. Appl Environ Microbiol 78:8441-8447

73. Rafieenia R (2013) Effect of nutrients and culture conditions on antibiotic synthesis in streptomycetes. Asian J Pharm 3:810815

74. Repka LM, Chekan JR, Nair SK, van der Donk WA (2017) Mechanistic understanding of lanthipeptide biosynthetic enzymes. Chem Rev 117:5457-5520 
75. Richter M, Rosselló-Móra R (2009) Shifting the genomic gold standard for the prokaryotic species definition. Proc Natl Acad Sci USA 106:19126-19131

76. Richter M, Rosselló-Móra R, Oliver Glöckner F, Peplies J (2016) JSpeciesWS: a web server for prokaryotic species circumscription based on pairwise genome comparison. Bioinformatics 32:929-931

77. Rungin S, Indananda C, Suttiviriya P, Kruasuwan W, Jaemsaeng R, Thamchaipenet A (2012) Plant growth enhancing effects by a siderophore-producing endophytic streptomycete isolated from a Thai Jasmine rice plant (Oryza sativa L. cv. KDML105). Antonie Van Leeuwenhoek 102:463-472

78. Sahunalu P (2003) Rehabilitation of salt affected lands in Northeast Thailand. Tropics 13:39-51

79. Saikia K, Bora LC (2021) Exploring actinomycetes and endophytes of rice ecosystem for induction of disease resistance against bacterial blight of rice. Eur J Plant Pathol 159:67-79

80. Saito H, Miura K (1963) Preparation of transforming deoxyribonucleic acid by phenol treatment. Biochim Biophys Acta 72:619-629

81. Saitou N, Nei M (1987) The neighbor-joining method a new method for reconstructing phylogenetic trees. Mol Biol Evol 4:406-425

82. Sanchez S, Demain AL (2002) Metabolic regulation of fermentation processes. Enzyme Microb Technol 31:895-906

83. Sasser M (2001) Identification of bacteria by gas chromatography of cellular fatty acids. Technical note\# 101. http: www.midi-inc.com

84. Schmerk C, Welander PV, Hamad MA, Bain KL, Bernards MA, Summons RE, Valvano MA (2015) Elucidation of the Burkholderia cenocepacia hopanoid biosynthesis pathway uncovers functions for conserved proteins in hopanoid-producing bacteria. Environ Microbiol 17:735-750

85. Seemann T (2014) Prokka: rapid prokaryotic genome annotation. Bioinformatics 30:2068-2069

86. Shen J, Kong L, Li Y, Zheng X, Wang Q, Yang W, Deng Z, You D (2019) A LuxR family transcriptional regulator AniF promotes the production of anisomycin and its derivatives in Streptomyces hygrospinosus var. beijingensis. Synth Syst Biotechnol 4:4048

87. Shirling EB, Gottlieb D (1966) Methods for characterization of Amycolatopsis species. Int J Syst Bacteriol 16:313-340

88. Sohlenkamp C, Geiger O (2016) Bacterial membrane lipids: diversity in structures and pathways. FEMS Microbiol Rev 40:133159

89. Stackebrandt E, Ebers J (2006) Taxonomic parameters revisited: tarnished gold standards. Microbiol Today 33:152-155

90. Tatusova T, DiCuccio M, Badretdin A, Chetvernin V, Nawrocki EP, Zaslavsky L, Lomsadze A, Pruitt KD, Borodovsky M, Ostell J (2016) NCBI prokaryotic genome annotation pipeline. Nucleic Acids Res 44:6614-6624

91. The UniProt Consortium (2021) UniProt: the universal protein knowledgebase in 2021. Nucleic Acids Res 49:D1

92. Thompson JD, Gibson TJ, Plewniak F, Jeanmougin F, Higgins DG (1997) The CLUSTAL X Windows interface: flexible strategies for multiple sequence alignment aided by quality analysis tools. Nucleic Acids Res 25:4876-4882

93. van Bergeijk DA, Terlouw BR, Medema MH, van Wezel GP (2020) Ecology and genomics of actinobacteria: new concepts for natural product discovery. Nat Rev Microbiol 18:546-558

94. Vértesy L, Aretz W, Knauf M, Markus A, Vogel M, Wink J (1999) Feglymycin, a novel inhibitor of the replication of the human immunodeficiency virus, fermentation, isolation and structure elucidation. J Antibiot 52:374-382

95. Waksman SA, Henrici AT (1943) The nomenclature and classification of the actinomycetes. J Bacteriol 46:337-341

96. Wakte K, Zanan R, Hinge V, Khandagale K, Nadaf A, Henry R (2017) Thirty-three years of 2-acetyl-1-pyrroline, a principal basmati aroma compound in scented rice (Oryza sativa L.): a status review. J Sci Food Agric 97:384-395

97. Wang X, Zhou H, Chen H, Jing X, Zheng W, Li R, Sun T, Liu J, Fu J, Huo L, Li Y-Z, Shen Y, Ding X, Müller R, Bian X, Zhang Y (2018) Discovery of recombinases enables genome mining of cryptic biosynthetic gene clusters in Burkholderiales species. Proc Natl Acad Sci USA 115:E4255-E4263

98. Wick RR, Judd LM, Gorrie CL, Holt KE (2017) Unicycler: Resolving bacterial genome assemblies from short and long sequencing reads. PLOS Comput Biol 13:e1005595

Page $17 / 24$ 
99. Williston EH, Zia-Walrath P, Youmans GP (1947) Plate methods for testing antibiotic activity of actinomycetes against virulent human type Tubercle Bacilli. J Bacteriol 54:563-568

100. Wu C, van der Heul HU, Melnik AV, Lübben J, Dorrestein PC, Minnaard AJ, Choi YH, van Wezel GP (2019) Lugdunomycin, an angucycline-derived molecule with unprecedented chemical architecture. Angew Chem Int Ed 58:2809

101. Xu T, Cao L, Zeng J, Franco CMM, Yang Y, Hu X, Liu Y, Wang X, Gao Y, Bu Z, Shi L, Zhou G, Zhou Q, Liu X, Zhu Y (2019) The antifungal action mode of the rice endophyte Streptomyces hygroscopicus OsiSh-2 as a potential biocontrol agent against the rice blast pathogen. Pestic Biochem Physiol 160:58-69

102. Yamaguchi T, Saburi Y (1955) Studies on the anti-trichomonal actinomycetes and their classification. J Gen Appl Microbiol 1:201-235

103. Yoon SH, Ha SM, Kwon S, Lim J, Kim Y, Seo H, Chun J (2017) Introducing EzBioCloud: a taxonomically united database of 16S rRNA gene sequences and whole-genome assemblies. Int J Syst Evol Microbiol 67:1613-1617

\section{Tables}

Table 1. Differential characteristics between Streptomyces $\mathrm{SBTS} 01^{\top}$ and related species of Streptomyces.

Strain: 1, Streptomyces spinosus SBTS01 ${ }^{\top} ; 2$, Streptomyces rochei NRRL B-2410'; 3 , Streptomyces naganishii NRRL ISP-5282 ${ }^{\top}$. + positive or present; w, weakly positive; -, negative or absent. Catalase was positive for all strains. All strains could produce acid from cellobiose, fructose, galactose, glucose, maltose, mannose, myo-inositol, mannitol, rhamnose, ribose, sucrose, trehalose and xylose, but not from dulcitol and sorbitol. All strains could hydrolyze adenine, starch, skim milk but not hippurate. They could not use pyridine, toluene, phenol and benzene. They could assimilate acetate, citrate, malate and propionate. All strains could grow at $1 \%$ and $3 \%$ but not at $10 \%, 15 \%$ and $20 \% \mathrm{NaCl}(\mathrm{w} / \mathrm{v})$. They could grow at $27^{\circ} \mathrm{C}$ and $37^{\circ} \mathrm{C}$ and between $\mathrm{pH} 5$ and pH 10 but they could not grow at $4^{\circ} \mathrm{C}$

and $55^{\circ} \mathrm{C}$.

\begin{tabular}{lccclcccc} 
Characteristics & $\mathbf{1}$ & $\mathbf{2}$ & $\mathbf{3}$ & Characteristics & $\mathbf{1}$ & $\mathbf{2}$ & $\mathbf{3}$ \\
\hline Acid production from: & & & & Organic acid assimilation: & & & \\
\hline Arabinose & + & + & - & benzoate & + & - & + \\
\hline salicin & + & + & - & tartrate & + & - & - \\
\hline Raffinose & + & + & - & Growth at: & & & \\
\hline Hydrolysis of: & & & & $\mathrm{NaCl} 5 \%((\mathrm{w} / \mathrm{v})$ & + & $\mathrm{w}$ & + \\
\hline L-tyrosine & - & + & + & $15^{\circ} \mathrm{C}$ & + & + & $\mathrm{w}$ \\
\hline xanthine & - & + & + & $45^{\circ} \mathrm{C}$ & $\mathrm{w}$ & - & - \\
\hline Esculin & + & + & - & $\mathrm{pH} 4$ & - & - & $\mathrm{w}$ \\
\hline & & & & $\mathrm{Melanin}$ pigment production & + & - & -
\end{tabular}


Table 2. Differential characteristics between Streptomyces $\mathrm{W} 18 \mathrm{~L} 9^{\top}$ and related species of Streptomyces.

Strain: 1, Streptomyces $\mathrm{W}_{18 \mathrm{~L}}^{\mathrm{T}} ;$; 2 , Streptomyces shenzhenensis DSM 42034 ;

\section{3, Streptomyces graminisoli NBRC $108883^{\top} ; 4$, Streptomyces jiujiangensis $\quad$ DSM 42115 ${ }^{\top} ; \quad$ 5, Streptomyces}

hyaluromycini DSM $100105^{\top}$. + positive or present; w, weakly positive; -, negative or absent. Catalase was positive for all strains. All strains could produce acid from cellobiose, fructose, galactose, glucose, mannose, myo-inositol, mannitol, ribose, sucrose, trehalose, but not dulcitol, salicin and sorbitol. All strains could hydrolyze skim milk but not L-tyrosine and adenine. They could assimilate acetate, citrate and propionate. They could not use phenol. All strains could grow at $1 \%$ but not at $10 \%, 15 \%$ and $20 \%$ $\mathrm{NaCl}(\mathrm{w} / \mathrm{v})$. They could grow at $27^{\circ} \mathrm{C}$ but could not grow at $4^{\circ} \mathrm{C}, 45^{\circ} \mathrm{C}$ and $55^{\circ} \mathrm{C}$. They could grow between pH 7 and pH 9 but not at $\mathrm{pH} 4$.

\begin{tabular}{|c|c|c|c|c|c|c|c|c|c|c|c|}
\hline Characteristics & 1 & 2 & 3 & 4 & 5 & Characteristics & 1 & 2 & 3 & 4 & 5 \\
\hline Acid production from: & & & & & & Organic acid assimilation: & & & & & \\
\hline Arabinose & + & + & + & - & + & benzoate & + & + & + & - & + \\
\hline Maltose & + & - & - & - & - & malate & + & + & + & - & - \\
\hline Raffinose & + & + & + & - & + & tartrate & + & - & + & - & + \\
\hline Rhamose & + & + & + & - & + & Use of phenolic compounds: & & & & & \\
\hline xylose & + & + & + & - & + & Pyridine (sigma) & - & - & - & - & + \\
\hline Hydrolysis of: & & & & & & Toluene & - & - & - & - & + \\
\hline xanthine & - & - & - & - & + & benzene & - & - & - & - & + \\
\hline Esculin & - & - & - & + & + & & & & & & \\
\hline Hippurate & - & + & - & + & - & Grow at: & & & & & \\
\hline Starch & + & + & + & - & + & $\mathrm{NaCl} 3 \%(\mathrm{w} / \mathrm{v})$ & + & + & + & + & - \\
\hline \multirow[t]{6}{*}{ urea } & + & - & - & - & + & $\mathrm{NaCl} 5 \%(\mathrm{w} / \mathrm{v})$ & - & w & + & w & - \\
\hline & & & & & & $15^{\circ} \mathrm{C}$ & + & - & + & - & w \\
\hline & & & & & & $37^{\circ} \mathrm{C}$ & + & + & + & + & - \\
\hline & & & & & & pH 5 & + & + & + & w & + \\
\hline & & & & & & $\mathrm{pH} 6$ & + & + & + & w & + \\
\hline & & & & & & $\mathrm{pH} 10$ & + & - & + & + & + \\
\hline
\end{tabular}

Table 3: Antimicrobial activity of strains $\mathrm{SBTS}^{\mathrm{T}}{ }^{\top}$ and $\mathrm{W} 18 \mathrm{~L} 9^{\top}$ to inhibit pathogens 


\begin{tabular}{|c|c|c|c|c|c|c|c|}
\hline \multirow[t]{4}{*}{ Strain/ methods } & \multicolumn{7}{|c|}{ Inhibition against pathogens } \\
\hline & Xoo & P. grisea & S. aureus & \multirow[t]{3}{*}{ MRSA 03120385} & \multirow{3}{*}{$\begin{array}{l}R . \\
\text { solani } \\
\text { AG8 }\end{array}$} & $H$. & \multirow{3}{*}{$\begin{array}{l}\text { C. lunata } \\
\text { BCC } \\
15558\end{array}$} \\
\hline & $\begin{array}{l}\text { PXO } \\
86\end{array}$ & $\begin{array}{l}\text { BRIP } \\
61689\end{array}$ & $\begin{array}{l}\text { ATCC } \\
29213\end{array}$ & & & DOAC & \\
\hline & & & & & & 1570 & \\
\hline \multicolumn{8}{|l|}{ SBTSO $^{\top}{ }^{\top}$} \\
\hline Dual culture; HPDA & $3+$ & $2+$ & $3+$ & $3+$ & $1+$ & $2+$ & $2+$ \\
\hline Dual culture; ISP 2 & $1+$ & $2+$ & $1+$ & $1+$ & $1+$ & $2+$ & $2+$ \\
\hline $\begin{array}{l}\text { Methanol extraction; HPDA } \\
(\mathrm{mm})\end{array}$ & 12 & 0 & 18.5 & 17 & - & - & - \\
\hline $\begin{array}{l}\text { Methanol extraction; } \\
\text { ISP2 (mm) }\end{array}$ & 0 & 0 & 8 & 0 & - & - & - \\
\hline \multicolumn{8}{|l|}{ W18L9 ${ }^{\top}$} \\
\hline Dual culture; HPDA & $2+$ & $3+$ & $3+$ & $3+$ & $3+$ & $1+$ & $2+$ \\
\hline Dual culture; ISP 2 & ni & $2+$ & $2+$ & $2+$ & $3+$ & $1+$ & $2+$ \\
\hline $\begin{array}{l}\text { Methanol extraction; HPDA } \\
(\mathrm{mm})\end{array}$ & 0 & 15 & 17.5 & 15 & - & - & - \\
\hline $\begin{array}{l}\text { Methanol extraction; ISP } 2 \\
(\mathrm{~mm})\end{array}$ & 0 & 8.5 & 15 & 13 & - & - & - \\
\hline Vancomycin & - & - & 19 & 18 & - & - & - \\
\hline \multicolumn{8}{|l|}{$500 \mathrm{ug} / \mathrm{ml}(\mathrm{mm})$} \\
\hline Streptomycin & 20 & - & - & - & - & - & - \\
\hline $500 \mathrm{ug} / \mathrm{ml}(\mathrm{mm})$ & & & & & & & \\
\hline
\end{tabular}

: 3+; strong inhibition, 2+; moderate inhibition, 1+; weak inhibition, ni; no inhibition, -; not done.

Table 4: Plant growth promoting (PGP) traits of Streptomyces spinosus $\mathrm{SBTS}_{01}^{\top}$ and Streptomyces shenzenensis subsp. endophyticus W18L9 ${ }^{\top}$

\begin{tabular}{|c|c|c|c|c|c|c|c|c|}
\hline \multirow[t]{2}{*}{ Strain } & \multicolumn{8}{|l|}{ PGP traits } \\
\hline & $\begin{array}{l}\text { ACC } \\
\text { deaminase }\end{array}$ & $\begin{array}{l}\text { Nitrogen } \\
\text { fixation }\end{array}$ & $\begin{array}{l}\text { Phosphate } \\
\text { solubilization }\end{array}$ & $\begin{array}{l}\text { Cellulase } \\
\text { production }\end{array}$ & $\begin{array}{l}\mathrm{HCN} \\
\text { Production }\end{array}$ & $\begin{array}{l}\text { Siderophore } \\
\text { production }\end{array}$ & $\begin{array}{l}\text { IAA } \\
\text { production } \\
(\mu \mathrm{g} / \mathrm{mL})\end{array}$ & $\begin{array}{l}\text { Cytokinin } \\
\text { production } \\
(\mathrm{mg} / \mathrm{L})\end{array}$ \\
\hline SBTSO $^{\top}{ }^{\top}$ & - & - & - & - & - & $\begin{array}{l}+ \\
\text { (hydroxymate } \\
\text { type) }\end{array}$ & 71 & 0.165 \\
\hline $\mathrm{W} 18 \mathrm{~L} 9^{\top}$ & + & + & + & + & - & $\begin{array}{l}+ \\
\text { (hydroxymate } \\
\text { type) }\end{array}$ & 150 & 0.169 \\
\hline
\end{tabular}


:-; negative result, +; positive result.

Table 5. The distribution of BGCs of Streptomyces spinosus SBTS01 ${ }^{\top}$ and Streptomyces shenzenensis subsp. endophyticus W18L9' 


\begin{tabular}{|c|c|c|c|c|c|}
\hline Gene type & product & Span (nt) & $\begin{array}{l}\text { Gene } \\
\text { similarity }\end{array}$ & $\begin{array}{l}\text { Most similar biosynthetic gene } \\
\text { cluster }\end{array}$ & Similarity \\
\hline \multicolumn{6}{|l|}{$\mathrm{SBTSO}^{\top}{ }^{\top}$} \\
\hline \multicolumn{6}{|l|}{ Terpene } \\
\hline & geosmin & $\begin{array}{l}524,641- \\
546,794\end{array}$ & $100 \%$ & Streptomyces sp. jing01 & $94 \%$ \\
\hline & albaflavenone & $\begin{array}{l}183,689- \\
204,612\end{array}$ & $100 \%$ & $\begin{array}{l}\text { Streptomyces hygroscopicus } \\
\text { subsp. limoneus }\end{array}$ & $94 \%$ \\
\hline & hopene & $1-21,432$ & $92 \%$ & $\begin{array}{l}\text { Streptomyces dengpaensis strain } \\
\text { XZHG99 }\end{array}$ & $75 \%$ \\
\hline & isorenieratene & $\begin{array}{l}18,402- \\
38,308\end{array}$ & $62 \%$ & Streptomyces sp. jing01 & $100 \%$ \\
\hline \multirow[t]{2}{*}{$\begin{array}{l}\text { Type } 1 \text { PKS } \\
\text { (T1PKS) }\end{array}$} & sceliphrolactam & $\begin{array}{l}89,955- \\
200,758\end{array}$ & $92 \%$ & $\begin{array}{l}\text { Streptomyces hygroscopicus } \\
\text { subsp. jinggangensis }\end{array}$ & $81 \%$ \\
\hline & antimycin & $1-48,820$ & $93 \%$ & $\begin{array}{l}\text { Streptomyces hygroscopicus } \\
\text { subsp. jinggangensis }\end{array}$ & $42 \%$ \\
\hline \multirow[t]{2}{*}{ T2PKS } & spore pigment & $\begin{array}{l}195,492- \\
268,003\end{array}$ & $83 \%$ & $\begin{array}{l}\text { Streptomyces } \\
\text { hygroscopicus subsp. limoneus }\end{array}$ & $91 \%$ \\
\hline & lugdunomycin & $1-45,736$ & $40 \%$ & Streptomyces sp. jing01 & $62 \%$ \\
\hline $\begin{array}{l}\text { RiPP } \\
\text { :Lanthipeptide }\end{array}$ & informatipeptin & $\begin{array}{l}302,814- \\
380,368\end{array}$ & $57 \%$ & $\begin{array}{l}\text { Streptomyces corchorusii DSM } \\
40340\end{array}$ & $87 \%$ \\
\hline $\begin{array}{l}\text { NRPS, } \\
\text { ladderane }\end{array}$ & ishigamide & $1-49,528$ & $100 \%$ & $\begin{array}{l}\text { Streptomyces corchorusii DSM } \\
40340\end{array}$ & $53 \%$ \\
\hline \multicolumn{6}{|l|}{ Others: } \\
\hline Siderophore & $\begin{array}{l}\text { desferrioxamin B / } \\
\text { desferrioxamine E }\end{array}$ & $\begin{array}{l}227,349- \\
239,118\end{array}$ & $83 \%$ & $\begin{array}{l}\text { Streptomyces hygroscopicus } \\
\text { subsp. limoneus }\end{array}$ & $100 \%$ \\
\hline & ectoine & $\begin{array}{l}88,957- \\
99,361\end{array}$ & $100 \%$ & Streptomyces sp. jing01 & $100 \%$ \\
\hline Alkaloid & anisomycin & $\begin{array}{l}185,220- \\
206,614\end{array}$ & $61 \%$ & $\begin{array}{l}\text { Candidatus Streptomyces } \\
\text { philanthi }\end{array}$ & $50 \%$ \\
\hline Pigment & melanin & $\begin{array}{l}333,875- \\
344,378\end{array}$ & $60 \%$ & $\begin{array}{l}\text { Streptomyces hygroscopicus } \\
\text { subsp. limoneus }\end{array}$ & $92 \%$ \\
\hline & melanin & $\begin{array}{l}240,779- \\
251,126\end{array}$ & $71 \%$ & Streptomyces sp. jing01 & $100 \%$ \\
\hline \multicolumn{6}{|l|}{ W18L9 ${ }^{\top}$} \\
\hline \multicolumn{6}{|l|}{ Terpene } \\
\hline & hopene & $1-20,148$ & $76 \%$ & Streptomyces scabiei & $77 \%$ \\
\hline & geosmin & $1-10,288$ & $100 \%$ & Streptomyces sp. 1-11 strain 1- 11 & $31 \%$ \\
\hline & albaflavenone & $1-10,143$ & $100 \%$ & Streptomyces sp. jing01 & $52 \%$ \\
\hline \multirow[t]{2}{*}{$\begin{array}{l}\text { Type } 1 \text { PKS } \\
\text { (T1PKS) }\end{array}$} & $\begin{array}{l}\text { rhizomide A / rhizomide B / } \\
\text { rhizomide C }\end{array}$ & $1-4,771$ & $100 \%$ & No hit & \\
\hline & $\begin{array}{l}\text { rhizomide } A \text { / rhizomide } B \text { / } \\
\text { rhizomide C }\end{array}$ & $1-3,488$ & $100 \%$ & No hit & \\
\hline
\end{tabular}




\begin{tabular}{|c|c|c|c|c|c|}
\hline & $\begin{array}{l}\text { rhizomide A / rhizomide B / } \\
\text { rhizomide C }\end{array}$ & $1-1,700$ & $100 \%$ & No hit & \\
\hline T2PKS & curamycin & $1-11,119$ & $57 \%$ & Streptomyces sp. DSM 40868 & $15 \%$ \\
\hline \multirow[t]{2}{*}{ T3PKS } & germicidin & $1-15,140$ & $100 \%$ & Streptomyces sp. BK141 & $8 \%$ \\
\hline & feglymycin & $1-16,377$ & $47 \%$ & Streptomyces sp. TLI 053 & $22 \%$ \\
\hline NRPS & xenotetrapeptide & $1-2,316$ & $100 \%$ & No hit & \\
\hline \multicolumn{6}{|l|}{ NRPS like } \\
\hline \multirow[t]{2}{*}{ Lipopeptide } & tolaasin I / & $1-1,056$ & $50 \%$ & Streptomyces sp. & $18 \%$ \\
\hline & tolaasin F & & & ADI96-15 & \\
\hline \multicolumn{6}{|l|}{ Other: } \\
\hline \multirow[t]{3}{*}{ Siderophore } & $\begin{array}{l}\text { desferrioxamin B } \\
\text { /desferrioxamine E }\end{array}$ & $\begin{array}{l}8,458- \\
20,227\end{array}$ & $83 \%$ & $\begin{array}{l}\text { Streptomyces ambofaciens ATCC } \\
23877\end{array}$ & $88 \%$ \\
\hline & flaviolin & $1-21,999$ & $50 \%$ & $\begin{array}{l}\text { Streptomyces hawaiiensis ATCC } \\
12236\end{array}$ & $58 \%$ \\
\hline & ectoine & $1-4,466$ & $100 \%$ & Streptomyces sp. BK387 & $66 \%$ \\
\hline Butyrolactone & A-factor & $1-2,461$ & $100 \%$ & Streptomyces sp. BK674 & $5 \%$ \\
\hline
\end{tabular}

Figures

\section{Figure 1}

16S rRNA gene-based neighbour-joining tree showing the phylogenetic relationships between Streptomyces spinosus SBTS01 ${ }^{\top}$ and Streptomyces shenzenensis subsp. endophyticus $\mathrm{W} 18 \mathrm{~L} 9^{\top}$ with other related strains in genus Streptomyces and Nocardia africana DSM $44491^{\top}$ as the out-group. Bootstrap values (>50\%) based on 1000 replicates are shown at the branch nodes. The scale bar represents 0.010 changes per nucleotide.
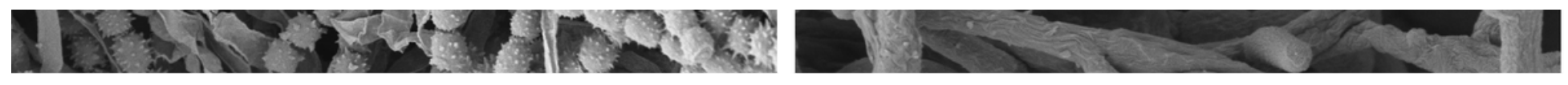

Figure 2 
Scanning electron microscope showed hyphae and spores of two strains grown on HPDA for 7 days at $27^{\circ} \mathrm{C}$. A) Strain SBTS01 ${ }^{\top}$ B) Strain $\mathrm{W} 18 \mathrm{~L}^{\top}$. Bar represents $1 \mu \mathrm{m}$.

\section{Supplementary Files}

This is a list of supplementary files associated with this preprint. Click to download.

- FigS1MP.pptx

- FigS2phylogenomictree.pptm

- FigS3polarlipid.pdf

- Tables1Genomefeature.docx

- TableS2FAMEs.docx

- Tables3Morpho.docx

- TableS4insilicots01.docx

- TableS5insilicow18.docx 